\title{
Elemental Concentrations in Biological Samples of Coronavirus Disease (COVID-19) and Other Pulmonary Disease Patients
}

\author{
Hassan Imran Afridi*, Tasneem Gul Kazi, Farah Naz Talpur, Jameel Ahmed Baig, \\ Ghulam Qadir Chanihoon, Ayaz Lashari, Ghulam Mustafa Channa
}

National Center of Excellence in Analytical Chemistry, University of Sindh, Jamshoro, Pakistan

Email: ^hassanimranafridi@yahoo.com

How to cite this paper: Afridi, H.I., Kazi, T.G., Talpur, F.N., Baig, J.A., Chanihoon, G.Q., Lashari, A. and Channa, G.M. (2021) Elemental Concentrations in Biological Samples of Coronavirus Disease (COVID-19) and Other Pulmonary Disease Patients. American Journal of Analytical Chemistry, 12, 162-187. https://doi.org/10.4236/ajac.2021.125011

Received: March 23, 2021

Accepted: May 18, 2021

Published: May 21, 2021

Copyright $\odot 2021$ by author(s) and Scientific Research Publishing Inc. This work is licensed under the Creative Commons Attribution International License (CC BY 4.0).

http://creativecommons.org/licenses/by/4.0/

(c) (i) Open Access

\begin{abstract}
Background: Recently, Coronavirus Disease 2019 (COVID-19) has been affected by the extreme acute respiratory syndrome coronavirus 2 (SARS-CoV-2) and has developed important global health anxiety. At this time, the treatment options for this disease are only moderately successful. Smoking has been related to COVID-19 and its mortality, and it has the potential to affect bacteriological and viral conversion, clinical effects, and treatment outcomes. Methods: The aim of this study was to determine the relationship between critical essential trace $\{$ zinc $(\mathrm{Zn})$, iron $(\mathrm{Fe})$, and copper $(\mathrm{Cu})\}$ and toxic $\{\mathrm{cad}-$ mium $(\mathrm{Cd})$ and nickel $(\mathrm{Ni})\}$ elements in human biological samples such as scalp hair, serum, saliva, blood, nasal fluid, and sputum of smoking and nonsmoking male COVID-19 patients ( $\mathrm{n}=139$, age range 25 - 38 years) from Hyderabad, Pakistan. For comparative purposes, the biological specimens of referent persons $(n=83)$, pulmonary Tuberculosis (T.B) patients $(n=67)$, Pneumonia $(n=56)$ of the same age groups were also be analyzed. Microwave oven mediated digestion method was employed, and digestion of samples was carried out with the help of 2:1 mixture solution of $\mathrm{HNO}_{3}(65 \%)$ and $\mathrm{H}_{2} \mathrm{O}_{2}(30 \%)$. Atomic absorption spectrometry was employed for the determination of elemental concentrations from the microwave oven employed digested samples. Results: The found average of essential elements ( $\mathrm{Zn}, \mathrm{Fe}$, and $\mathrm{Cu}$ ) in biological specimens of smoker and nonsmoker male COVID-19, T.B, and Pneumonia patients was found to lower, whilst cadmium and nickel were found to be higher when compared with samples from referents $(\mathrm{p}<0.001)$. Conclusions: Improved elemental $(\mathrm{Cu}, \mathrm{Fe}, \mathrm{Zn})$ concentrations may also decrease the risk of bacterial co-infection by enhancing the mucociliary clearance and respiratory epithelial barrier function, in addition to providing direct antibacterial effects against $S$. pneumoniae. Our findings also suggest that higher $\mathrm{Cd}$ and $\mathrm{Ni}$ concentrations are linked to cigarette smoking, which could
\end{abstract}


lead to COVID-19 and other lung-infected diseased recurrences. However, further clinical and experimental research is required.

\section{Keywords}

COVID-19, Other Lung Infected Diseases, Essential Trace Elements, Toxic Elements, Biological Samples, Age Ranged 25 - 38 Years

\section{Introduction}

A story coronavirus $(\mathrm{CoV})$ is another strain of coronavirus. The infirmity achieved by the novel coronavirus erupted in Wuhan, China, has been named coronavirus disorder 2019 (COVID-19) - "CO" speaks to crown, "VI" for disease, and "D" for illness. The COVID-19 contamination is another disease associated with a comparative gathering of contaminations as Severe Acute Respiratory Syndrome (SARS) and a couple of sorts of standard infection [1].

The 2019-20 coronavirus pandemic was confirmed to have reached Pakistan in February 2020. As of 1 April 2020, the number of confirmed cases in the country is over 2000, with 82 recoveries and 26 deaths. Punjab is currently the region with the highest number of cases at over 700 (Coronavirus in Pakistan, $1^{\text {st }}$ April 2020) [1]. Multiple regions across the country have imposed lockdowns until early April to stem the outbreak (COVID-19 Daily Situation Report-NIH Pakistan, $1^{\text {st }}$ April 2020) [1]. These include Punjab (CM Punjab Usman Buzdar announces lockdown in Punjab, $23^{\text {rd }}$ March 2020) [1], Sindh outbreak (Sindh decides to go into COVID-19 lock down, $22^{\text {nd }}$ March 2020) [1], Balochistan (Balochistan goes into lockdown until April 7, 25 ${ }^{\text {th }}$ March 2020) [1] and Azad Kashmir (Azad Jammu and Kashmir PM announce three-week lockdown to combat the virus, $23^{\text {rd }}$ March 2020) [1] while Gilgit-Baltistan has imposed lockdown indefinitely (GB Govt decides to observe lockdown for an indefinite period, $23^{\text {rd }}$ March 2020) [1].

Pakistan at present has the third-greatest number of avowed cases in Asia, after India and Iran, the second-greatest number of confirmed cases in South Asia, coming after India, and the twelfth most elevated number of affirmed cases on the planet. In spite of this, the quantity of passing in the nation and case casualty rate has remained generally low contrasted with most different nations on the planet and Asia, at $2.10 \%$ contrasted with the worldwide normal of $4.3 \%$ (starting at 15 July) [2]. On 14 June, day by day new affirmed case numbers arrived at their top, with 6825 new cases recorded, yet from that point forward, new case checks and the level of individuals testing positive have inclined downwards. In late June, the quantity of dynamic cases in Pakistan settled, and starting in July began demonstrating a huge descending pattern. On 03 July, Pakistan's recuperations surpassed the quantity of dynamic cases just because 8929 recuperations were recorded, making $51 \%$ of affirmed cases recuperations, and only six days after the fact on 09 July, this figure outperformed $60 \%$. Starting on 
4 August 2020 there have been around 282,000 affirmed cases, 256,000 recuperations, and 6000 passings in the nation. Sindh has recorded the most cases at around 122,000 and has additionally recorded the most passings due to COVID19 , around 2200 to date. The country was put under the nation over lock down until 9 May [2]. Which was begun on the first of April anyway later extended twice [2]. Later the lockdown was facilitated in phases [3].

Trace elements act as a part of metalloenzymes and contribute to biological functions such as oxygen transport, free-radical scavenging, structural organization of macromolecules, and hormonal activity. These facts make the trace elements more important. The existence of a balance between different essential trace elements is obvious in the human body for normal activities. This balance is important for the proper functioning of several metabolic and physiological processes [4]. Imbalance in the level of trace elements is related to some pathologic circumstances, causing many disorders. Several evidences specified that various metals act as oxidants in the human environment and are produced in tissues throughout metabolic and inflammatory processes. They can act at a number of phases in malignant alteration tempting lasting DNA sequence variations. A large number of researchers are working on this subject [4].

Zinc $(\mathrm{Zn})$ is a basic metal being associated with an assortment of organic procedures because of its capacity as a cofactor, flagging particle, and auxiliary component [4]. The most basic job of zinc is shown for the safe framework. Quickly, zinc controls the expansion, separation, development, and working of leukocytes and lymphocytes [5]. Zinc assumes a flagging job engaged with the tweak of provocative reactions (3). It is likewise a segment of nourishing invulnerability [5]. Correspondingly, adjustment of zinc status altogether influences invulnerable reaction bringing about expanded vulnerability to provocative and irresistible ailments including AIDS, measles, jungle fever, tuberculosis, and pneumonia [6]. Copper $(\mathrm{Cu})$ is a fundamental minor component for people [7]. $\mathrm{Cu}$ insufficiency indications in human remember inadequacies for white platelets, bone and connective tissue anomalies, and resistant responses [7]. Unfriendly impacts of lacking $\mathrm{Cu}$ on safe capacity show up generally articulated in newborn children and more seasoned individuals. Babies with hereditary issues that bring about extreme $\mathrm{Cu}$ inadequacy experience the ill effects of incessant and serious diseases [8]. Dietary $\mathrm{Cu}$ insufficiency influences both intrinsic and versatile resistance [8]. Truth be told, $\mathrm{Cu}$-inadequate people show extraordinary helplessness to diseases. Additionally, $\mathrm{Cu}$ can slaughter a few irresistible infections, for example, bronchitis infection, poliovirus, human immune deficit infection type 1 (HIV-1), other single-or twofold abandoned DNA and RNA infections [8]. $\mathrm{Cu}$ induced viral slaughtering might be interceded by means of ROS [9], and in such manner, $\mathrm{Cu}+$ and $\mathrm{H}_{2} \mathrm{O}_{2}$ assume the fundamental jobs [10]. The interaction slaughtering of microbes, infections, and yeasts, on metallic $\mathrm{Cu}$ surfaces, is very much examined [10].

Iron being an essential component for the development of practically all body frameworks, is found in the body in an assortment of complex restricting pro- 
teins, for example, transferrin, lactofserrin, and ferritin [11]. Besides, it is likewise significant for both parasite and host cells quality consequently microbes are engaged by high similitude up taking procedures [11]. Iron is a crucial component for all creatures since it capacities as a fundamental key factor for metabolic courses and chemical capacity. Cells control iron reactivity, accessibility, and flimsiness to stop free extreme harm to proteins, ribonucleic acids, and cell films. Iron is important and iron inadequacy altogether harms cell multiplication and resistant capacity [12].

Most of the studies have concentrated on the carcinogenesis that is induced by metals, oxidative stress produced by metals being the most significant mechanism [13]. It is well known that free radicals play important role in the structural modification of DNA with consequent development of changes, which initiate the carcinogenesis [11] [12] [13]. Imbalance of trace elements combined with the structure of enzymes (for antioxidant protection), facilitates these processes. The particular effect of antioxidant enzymes (glutathion peroxidase and glutathion transferase) is specified considerably by the existence of active selenium [12] in the active centre structure and the effect of superoxide dismutases is mostly produced by the existence of Copper, zinc, and manganese [12].

There are some reasons to suppose that sufficient inhibition of deteriorations of oncological pathology after a surgical involvement and/or radiotherapy (which provokes generation of free radicals) should be accomplished taking into account the content of toxic elements (cadium, lead, nickel, arenic) and their quantity [13]. Exposure to ecological contaminants such as metals counting nickel, chromium, cadmium, and arsenic is classified in Group 1 category of carcinogen by the International Agency for Research on Cancer [13]; it also reports lead as a suspected human carcinogen (Group 2A) (International Agency for Cancer Research, 1993) and also mercury as possibly carcinogenic to humans (Group 2B) [13].

Coronavirus associated respiratory syndrome spread very quickly in human, once the novel strain was isolated and identified in December 2019. The novel Coronavirus was recognized as COVID-19 in Wuhan city of China, which is responsible for severe life-threatening respiratory syndrome including pneumonia and death. Since it spread out from an originating place, it has started spreading very quickly in different countries, the main reason for the current pandemic is the traveling of COVID-19 carrier individuals across the world. Pakistan also affected by this pandemic state because Pakistan has a large number of exchanged students, scientist, tourists, and business community, therefore, COVID-19 has been started infecting Pakistani population, Although the number of infected individuals is very less as compared to other affected regions, statistics analysis reveals that there is significant increase pattern in the number of infected positive with time.

This is the first study to determine the essential trace and toxic elemental level in the biological samples of COVID-19 smoker and nonsmoker male patients. This is our primary outcome, because at this time COVID-19 is a pandemic all 
over the world. No one person knows the complete history of this disease. For the comparison purpose, we have selected two diseases, pulmonary Tuberculosis and viral Pneumonia, as a secondary outcome. This study is carried out first time in the world, therefore we can not compare our results with other studies.

In this study, we will discuss the deficiency or efficiency of essential trace metals and known carcinogenic hazardous metals in scalp hair, blood, serum, nasal fluid, sputum and saliva samples of smoker and nonsmoker COVID-19 and other lung infected diseased (pulmonary Tuberculosis and Pneumonia) patients, age ranges 25 - 38 years. Although correlations between essential trace and toxic elemental exposure and COVID-19 patients are not well documented, therefore, this type of research is needed in order to determine the exact mechanisms of metal-induced carcinogenesis.

\section{Materials and Methods}

\section{Recruitment}

For the initiation of this study, prior permission was obtained from the ethical review committee of NCEAC, University of Sindh, Jamshoro, Pakistan.

\section{Study design and pretreatment}

For this study, we had tried our best to collect the biological samples of COVID 19 patients, but due to lockdown of the whole world, we had collected the biological samples of our relatives, friends and other our family friends biological samples $(\mathrm{N}=139)$, who were affected by COVID-19 diseases. All these our affected patients were admitted to different hospitals. We had collected these samples during the period March 2020-October 2020. This was primary outcome of our study. For secondary outcome, we had collected the biological samples of 67 pulmonary TB patients ( 34 nonsmokers and 33 smokers) and 56 viral pneumonia patients (289 non smokers and 27 smokers).

The biological samples of one hundred thirty-nine COVID-19 patients (including Non-Smokers and Smokers) were collected; all these patients were registered, during March 2020-October 2020. An oral session was conducted at the patients' house for information purposes and the contributors/subjects were given knowledge about the study need and pattern. A written consent form filled and signed by the patients was provided before the collection of samples. Another informational form was filled with information about lifestyle, eating habits and work history of the patients. All COVID-19 patients lied in age group of 25 - 38 years. For the comparative study, the COVID-19 was divided into two groups i.e. the smoker and nonsmoker COVID-19 patients. Out of 83 of the healthy referents, 39 were smokers and 44 were non-smokers. While from COVID-19 patients, 67 were non-smokers, whereas, 72 were smokers, making a grand total of 139 patients (Table 1). According to the seventh edition of COVID-19's diagnosis and treatment plan issued by the Chinese National Health Commission, patients with COVID-19 are divided into 3 main types according to the following clinical manifestations: 1) mild-with fever, respiratory or digestive symptoms, and physician-diagnosed pneumonia by chest computed 
Table 1. Demographic information of smoker and non smoker referents and Covid-19 patients.

\begin{tabular}{|c|c|c|c|c|c|c|c|c|}
\hline \multirow{3}{*}{ Characteristics } & \multicolumn{4}{|c|}{ Non Smokers } & \multicolumn{4}{|c|}{ Smokers } \\
\hline & \multirow[b]{2}{*}{ Referents } & \multicolumn{3}{|c|}{ Covid-19 patients $(n=67)$} & \multirow[b]{2}{*}{ Referents } & \multicolumn{3}{|c|}{ Covid-19 patients $(n=72)$} \\
\hline & & Mild $(\mathrm{n}=52)$ & $\begin{array}{l}\text { Severe } \\
(\mathrm{n}=11)\end{array}$ & $\begin{array}{l}\text { Critical } \\
(\mathrm{n}=04)\end{array}$ & & $\begin{array}{c}\text { Mild } \\
(\mathrm{n}=59)\end{array}$ & $\begin{array}{l}\text { Severe } \\
(\mathrm{n}=10)\end{array}$ & $\begin{array}{l}\text { Critical } \\
(\mathrm{n}=03)\end{array}$ \\
\hline \multicolumn{9}{|c|}{ Signs and Symptoms } \\
\hline Fever & ------- & 52 & 11 & 04 & ------- & 59 & 09 & 03 \\
\hline Cough & ------- & 49 & 10 & 04 & ------- & 53 & 07 & 03 \\
\hline Chest distress & ------- & 48 & 09 & 03 & ------- & 45 & 07 & 03 \\
\hline Myalgia or fatigue & ------- & 35 & 10 & 03 & ------- & 20 & 05 & 03 \\
\hline Anorexia & ------- & 22 & 04 & 03 & ------- & 11 & 05 & 03 \\
\hline Diarrhea & ------- & 20 & 06 & 03 & $-\cdots---$ & 12 & 04 & 03 \\
\hline Dyspnea & ------- & 00 & 00 & 03 & ------- & 00 & 00 & 00 \\
\hline Palpitation & -------- & 14 & 00 & 04 & ------- & 09 & 00 & 03 \\
\hline Chest pain & -------- & 17 & 05 & 04 & ------- & 14 & 05 & 03 \\
\hline
\end{tabular}

tomography (CT); 2) severe-one of the following conditions: shortness of breath and respiratory rate $\geq 30$ times/minute, oxygen saturation $\leq 93 \%$ at rest, or chest CT imaging showing lesion progression of more than $50 \%$ within 24 48 hours; 3 ) critical-meet any of the following rules: respiratory failure and need for mechanical ventilation, shock, and any other organ failure needing critical care and treatment.

All these volunteers first went through severe acute respiratory syndrome coronavirus 2 (SARS-CoV-2) RNA detection test. This test was performed through the Nasopharyngeal/Oropharyngeal Swab through PCR (Qualitative). This test was followed by clinical examination by the specialist, for confirmation of COVID-19 and later the sample collection was carried out in the presence of specialist doctors present at different hospitals of Sindh, Pakistan at the production of signed consent form by the COVID-19 patients. At the start, biochemical data, height, weight and blood pressure data were collected for each volunteer (Table 2).

For comparison purpose, the biological samples of 67 pulmonary TB patients (34 nonsmokers and 33 smokers) and 56 viral pneumonia patients (29 nonsmokers and 27 smokers) were collected, which were also registered during March 2020-October 2020. We had collected the biological samples of 67 pulmonary TB patients and 56 viral pneumonia patients during March 2020-October 2020. All these patients were registered at Chest Disease Institute (CDI), Kotri. The biochemical parameters of pulmonary TB patients and viral pneumonia patients were given in supplementary Table 1 . The patients belong to areas that lie under the poverty line of district Hyderabad of Sindh, Pakistan. An oral session was conducted at the hospital for information purposes and the contributors/ subjects were given knowledge about the study need and pattern. It was also elaborated to them for their information that this study will help in finding the nutritional drawbacks that may be helping hand towards the spread of TB. A 
written consent form filled and signed by the patients was provided before the collection of samples. Another informational form was filled with information about lifestyle, eating habits and work history of the patients. All these volunteers first went through bacterial tests followed by clinical examination by the specialist, for confirmation of TB and later the sample collection was carried out in the presence of specialist doctor present at CDI-Kotri at the production of signed consent form by the volunteer. All subjects agreed to receive anti-TB therapy and attend all study visits in CDI, Kotri and sign the informed consent. At the start, biochemical data, height, weight and blood pressure data were collected for each volunteer (Table 3).

Table 2. Anthropometric information of smoker and non smoker referents and Covid-19 patients.

\begin{tabular}{|c|c|c|c|c|}
\hline \multirow{2}{*}{ Important biochemical tests } & \multicolumn{2}{|c|}{ Non Smokers } & \multicolumn{2}{|c|}{ Smokers } \\
\hline & Referents & Covid-19 patients & Referents & Covid-19 patients \\
\hline BMI $\left(\mathrm{kg} / \mathrm{m}^{2}\right)$ & $20.8 \pm 2.46$ & $18.9 \pm 3.86$ & $19.9 \pm 2.11$ & $17.5 \pm 1.61$ \\
\hline Hemoglobin [g/dL] & $14.4 \pm 0.69$ & $6.15 \pm 0.53$ & $12.5 \pm 0.85$ & $5.84 \pm 0.62$ \\
\hline Leucocyte $\left[10^{3} / \mu \mathrm{L}\right]$ & $7250 \pm 450$ & $8785 \pm 825$ & $7520 \pm 490$ & $9090 \pm 880$ \\
\hline CRP (mg/L) & $1.25 \pm 0.10$ & $15.6 \pm 2.30$ & $1.38 \pm 0.25$ & $16.9 \pm 1.95$ \\
\hline Serum cholesterol $[\mathrm{mg} / \mathrm{dL}]$ & $145 \pm 12.5$ & $118 \pm 8.45$ & $135 \pm 6.85$ & $110 \pm 7.50$ \\
\hline $\mathrm{HDL}[\mathrm{mg} / \mathrm{dL}]$ & $47.5 \pm 1.82$ & $34.5 \pm 1.57$ & $44.3 \pm 2.05$ & $31.8 \pm 2.12$ \\
\hline \multirow{2}{*}{$\mathrm{LDL}[\mathrm{mg} / \mathrm{dL}]$} & $119 \pm 9.75$ & $95.2 \pm 5.85$ & $126 \pm 7.65$ & $92.9 \pm 8.45$ \\
\hline & $114-125$ & $93.4-98.2$ & $122-129$ & $88.5-97.0$ \\
\hline Triglyceride [mg/dL] & $103 \pm 7.55$ & $63.8 \pm 7.55$ & $106 \pm 6.45$ & $64.5 \pm 5.05$ \\
\hline Total Albumin [g/L] & $43.5 \pm 4.82$ & $35.9 \pm 3.85$ & $42.5 \pm 2.75$ & $32.9 \pm 3.19$ \\
\hline Total protein $[\mathrm{g} / \mathrm{L}]$ & $34.8 \pm 3.05$ & $22.9 \pm 1.16$ & $32.7 \pm 1.69$ & $19.4 \pm 0.95$ \\
\hline Vitamin D (ng/mL) & $26.9 \pm 1.30$ & $6.98 \pm 0.55$ & $25.2 \pm 1.05$ & $5.69 \pm 0.42$ \\
\hline
\end{tabular}

Table 3. Anthropometric information of smoker and non smoker referents and pulmonary respiratory disease patients.

\begin{tabular}{|c|c|c|c|c|c|c|}
\hline \multirow{2}{*}{$\begin{array}{c}\text { Important } \\
\text { biochemical tests }\end{array}$} & \multicolumn{3}{|c|}{ Non Smokers } & \multicolumn{3}{|c|}{ Smokers } \\
\hline & Referents & T.B patients & Pneumonia & Referents & T.B patients & Pneumonia \\
\hline BMI $\left(\mathrm{kg} / \mathrm{m}^{2}\right)$ & $20.8 \pm 2.46$ & $18.3 \pm 1.52$ & $18.4 \pm 0.93$ & $19.9 \pm 2.11$ & $17.2 \pm 1.31$ & $15.6 \pm 1.63$ \\
\hline Hemoglobin [g/d L] & $14.4 \pm 0.69$ & $12.05 \pm 0.59$ & $9.92 \pm 1.74$ & $12.5 \pm 0.85$ & $11.4 \pm 0.75$ & $9.80 \pm 0.63$ \\
\hline Leucocyte $\left[10^{3} / \mu \mathrm{L}\right]$ & $7250 \pm 450$ & $8260 \pm 245$ & $8530 \pm 492$ & $7520 \pm 490$ & $8350 \pm 362$ & $8650 \pm 352$ \\
\hline CRP (mg/L) & $1.25 \pm 0.10$ & $6.17 \pm 0.33$ & $9.52 \pm 0.46$ & $1.38 \pm 0.25$ & $8.05 \pm 0.62$ & $11.4 \pm 1.25$ \\
\hline Serum cholesterol $[\mathrm{mg} / \mathrm{dL}]$ & $145 \pm 12.5$ & $132 \pm 7.95$ & $126 \pm 7.99$ & $135 \pm 6.85$ & $129 \pm 7.65$ & $119 \pm 8.02$ \\
\hline $\mathrm{HDL}[\mathrm{mg} / \mathrm{dL}]$ & $47.5 \pm 1.82$ & $35.3 \pm 1.15$ & $34.0 \pm 0.95$ & $44.3 \pm 2.05$ & $35.0 \pm 1.09$ & $32.5 \pm 1.32$ \\
\hline $\mathrm{LDL}[\mathrm{mg} / \mathrm{dL}]$ & $119 \pm 9.75$ & $95.9 \pm 5.19$ & $85.9 \pm 7.35$ & $126 \pm 7.65$ & $105 \pm 6.84$ & $97.6 \pm 8.09$ \\
\hline Total Albumin [g/L] & $43.5 \pm 4.82$ & $38.7 \pm 1.99$ & $37.5 \pm 2.50$ & $42.5 \pm 2.75$ & $38.2 \pm 2.50$ & $36.0 \pm 1.44$ \\
\hline Total protein $[\mathrm{g} / \mathrm{L}]$ & $34.8 \pm 3.05$ & $29.8 \pm 1.35$ & $26.2 \pm 0.90$ & $32.7 \pm 1.69$ & $27.5 \pm 0.84$ & $24.8 \pm 1.74$ \\
\hline Vitamin D (ng/mL) & $26.9 \pm 1.30$ & $13.0 \pm 0.73$ & $10.9 \pm 0.93$ & $25.2 \pm 1.05$ & $12.2 \pm 0.45$ & $10.5 \pm 0.60$ \\
\hline
\end{tabular}


All 67 TB and 56 viral pneumonia volunteers were in the age group of 25 - 38 years; and all patients fell on the selection criteria of acid-fast bacilli sputum test; radiographic test, clinical test and microscopic test all elaborating pulmonary $\mathrm{TB}$ associated abnormalities in the samples. The inclusion criteria for TB patients included: age $\geq 16$ years, smear-positive case of pulmonary $\mathrm{TB},<1$ week of antiTB medication at the time of sample collection, conformism to take anti-TB medication in Tbilisi, completion of the $72 \mathrm{~h}$ summon up instrument at baseline (week 1) and the serial $22 \mathrm{~h}$ recalls during week 2, and a signed informed approval. The common symptoms of viral pneumonia are Influenza (flu), respiratory syncytial virus (RSV) and rhinoviruses (common cold). This viral pneumonia is usually milder and can improve in one to three weeks without treatment.

Selection for healthy referents was done on the basis of: 1) that the referent had no fever and or any breathing track-based disease/infection at the time of selection and 2) no known evidence of having TB in the past for at least 2 years from the time of sample collection. Probability sampling method was used for healthy individuals' selection. Medical check-up of all 83 healthy referents was done by a qualified physician before the collection of biological samples.

All 139 COVID-19 patients were in the age group of 25 - 38 years; and all the patients fell on the selection criteria of acid-fast bacilli sputum test; radiographic test, clinical test and microscopic test all elaborating pulmonary TB associated abnormalities in the samples. The inclusion criteria for COVID-19 patients included: age $\geq 25$ years, smear-positive case of pulmonary Tuberculosis case and the COVID-19 patients signed informed approval. Excluded patients were either being re-treated for the TB and were either suffering from multi-drug resistant TB and/or had extra Pulmonary TB.

\section{Ethical consideration}

An ethical approval was obtained from ethical committee of National Centre of Excellence in Analytical Chemistry (NCEAC) and verbally consent was taken by the patient's relatives and friends, prior to sample collection. For consent collection from volunteers and/or their legal guardians was done by strictly following Declaration of Helsinki code. Volunteers were coded with confidential identifiers to mask the volunteer's identity. All the data of COVID-19 patients were kept confidential and was accessible only by the principle investigator of the project and physician specialist.

\section{Sample collection}

\section{Blood sample collection}

Aseptically blood was drawn from each volunteers' veins, with the help of a syringe. This process of drying blood was performed by a registered male nurse, with the help of $5 \mathrm{~mL}$ sterile-one time use only, syringe. Area of puncture was cleaned with the help of alcohol swab-containing zero elements, sealed in a plastic covering. This type of alcohol swab was chosen only to avoid any type of infection and contamination. BD (Oxford, UK) Vacutainer-(Trace Element tube with potassium-EDTA) was used for the collection of blood samples to be 
analyzed for trace elements. Before the collection of $5 \mathrm{ml}$ of blood sample, each volunteer was advised to fast overnight. Sample tubes were kept away from direct sunlight and container tubes were folded with $\mathrm{Al}$ foil to avoid any possible sunlight interaction with blood samples. Once travelled to a testing facility, the blood samples were allowed to sit for 1 hour at room temperature followed by $3000 \mathrm{rpm}$ centrifugation of each sample for 15 minutes to separate out serum from blood cells. Hemolytic sera were discarded. The collected samples, after centrifugation, were refrigerated at $-20^{\circ} \mathrm{C}$ for further analysis.

\section{Saliva sample collection}

A sterile plastic container, free from any elemental and pathogenic contamination, was provided to each volunteer. The container was pre-labelled with each volunteers' confidential identifier number. Every volunteer was directed to collect the saliva into their mouth cavity and spit into plastic container to reach the point of $5 \mathrm{ml}$. this approach of saliva collection is termed as direct collection.

\section{Sputum sample collection}

Male nurses were advised to direct each volunteering patient and referent to reach the mark of $5 \mathrm{ml}$ of a sterile plastic container that was provided for each participation member with pre-labelled volunteers' confidential identifier number. All the samples were then transported to National centre of Excellence in Analytical Chemistry (NCEAC), Jamshoro, in protected container to avoid exposure to direct sunlight, for analysis. Sputum collection from healthy participants was induced with the mediation of nebulized $4.5 \%$ hypertonic saline.

\section{Nasal fluid sample collection}

Small plastic spoon having dimensions $10 \mathrm{~mm} \times 5 \mathrm{~mm} \times 2 \mathrm{~mm}$ was employed for the collection of nasal fluids. Each sample was centrifuged after the collection of $1.5 \mathrm{~mL}$ of sample into Eppendorf.

\section{Scalp hair sample collection}

Stainless steel scissors were used for the collection of hair samples of about 0.5 $\mathrm{g}(0.5-2.0 \mathrm{~cm}$ long) from each diseased and healthy participant. The scissors were thoroughly washed and cleaned with alcohol swab before and after cutting hair of each participant. Hair samples were collected from the back of the head and stored in sterile plastic bags. After collection of samples each bag was marked with confidential identifier number for each participant. These plastic bags were attached with questioner provided to each volunteer and were stored for digestion and further analysis.

\section{Apparatus}

A Milestone microwave oven (Rotar MPR-300/12S, pressure 35 bar, with maximum temperature $300^{\circ} \mathrm{C}$ ) was used. Elemental analysis was performed on a Hitachi (Tokyo) Model 180-50, S.N.5721-2 atomic absorption (AA) spectrophotometer equipped with a flame burner, graphite furnace GA-3, and a deuterium lamp background corrector. Hollow-cathode lamps (Mitorika Company) were used. Operational parameters, including lamp currents and wavelength, were those, recommended by the manufacturer. The signals measured were the heights of 
the absorbance peaks for the flame absorption mode, and integrated absorbance values (peak area) were used for the graphite furnace. The instrumental conditions are reported in Table 4(a), Table 4(b). The $\mathrm{Cu}, \mathrm{Fe}$ and $\mathrm{Zn}$ in scalp hair, blood and serum samples were measured under optimised operating conditions using flame atomic absorption spectrometry (FAAS) mode with an air-acetylene flame, whlist in the saliva, sputum and nasal fluids these samples were determined through electrothermal atomic absorption spectrometry (ETAAS) mode. Electrothermal atomic absorption spectrometer (ETAAS) was utilized for cadmium and nickel analysis. The instrument conditions were given in Table 5(a), Table 5(b). Signals were measured as absorbance peaks in the flame absorption mode, whereas integrated absorbance values (peak area) were determined in the graphite furnace. The collected samples were heated/digested by means of domestic microwave oven model Pel (PMO23) which has the heating power of 900 W. Acid washed polytetrafluroethylene (PTFE) vessels/flasks were utilized for preparation and storage of prepared solutions. Reagents blanks and complex working standards were run in parallel and corrections were made as required.

Table 4. (a) Measurement conditions for flame ionization (FAAS). (b) Measurement conditions for electrothermal atomization (ETAAS).

(a)

\begin{tabular}{ccccccc}
\hline Parameters & Lamp current $(\mathrm{mA})$ & Wave length $(\mathrm{nm})$ & Slit width $(\mathrm{nm})$ & Burner height $(\mathrm{mm})$ & Oxidant (Air) L/min Fuel (Acetylene) L/min \\
\hline $\mathrm{Zn}$ & 7.5 & 214 & 0.2 & 7.5 & 17 & 2 \\
$\mathrm{Fe}$ & 7.5 & 248.5 & 1.3 & 7.5 & 17 & 2 \\
$\mathrm{Cu}$ & 7.5 & 324.8 & 1.3 & 7.5 & 17 & 2 \\
\hline
\end{tabular}

(b)

\begin{tabular}{|c|c|c|c|c|c|}
\hline Parameters & $\mathrm{Cu}$ & $\mathrm{Fe}$ & $\mathrm{Zn}$ & $\mathrm{Ni}$ & $\mathrm{Cd}$ \\
\hline Lamp current (mA) & 7.5 & 10.0 & 10 & 10 & 7.5 \\
\hline Wavelength (nm) & 324.8 & 248.3 & 213.8 & 232.0 & 283.3 \\
\hline Slit- width (nm) & 1.3 & 0.2 & 1.3 & 0.2 & 1.3 \\
\hline Background correction & $\mathrm{D}_{2}$ & $\mathrm{D}_{2}$ & $\mathrm{D}_{2}$ & $\mathrm{D}_{2}$ & $\mathrm{D}_{2}$ \\
\hline cuvette & Tube & Tube & Cup & Tube & Cup \\
\hline Carrier gas (mL/minute) & 200 & 200 & 200 & 200 & 200 \\
\hline Sample volume $(\mu \mathrm{L})$ & 10 & 10 & 100 & 100 & 100 \\
\hline \multicolumn{6}{|c|}{ Temperature Program } \\
\hline Dry & $80-120 / 15$ & $80-120 / 15$ & $80-120 / 15$ & $80-120 / 15$ & $80-120 / 15$ \\
\hline Ash & $300-600 / 15$ & $300-600 / 15$ & $300-600 / 15$ & $300-700 / 15$ & $300-600 / 15$ \\
\hline Atomization & $2500-2600 / 3$ & $2400-2500 / 3$ & $2000-2100 / 3$ & $2500-2600 / 3$ & $1500-1800 / 3$ \\
\hline Cleaning & $2600-2700 / 1$ & $2500-2600 / 1$ & $2100-2200 / 1$ & $2600-2800 / 1$ & $1800-2000 / 1$ \\
\hline
\end{tabular}


Table 5. (a) Elemental concentrations in certified samples (CRM) by microwave digestion method (MWD); (b) Spike recovery study in the biological samples (sputum, saliva and nasal fluid) of referent subjects (added $\mathrm{Zn} / \mathrm{Cu} / \mathrm{Fe} / \mathrm{Cd} / \mathrm{Ni}$ in micrograms per gram).

(a)

\begin{tabular}{|c|c|c|c|c|}
\hline Elements & Certified values & MWD & $\mathrm{T}_{\text {value }}{ }^{\mathrm{a}}$ & $\%$ Recovery $^{\mathrm{b}}$ \\
\hline \multicolumn{5}{|c|}{ CRM of whole serum (mg/L) } \\
\hline Iron & $1.30 \pm 0.3$ & $1.286 \pm 0.087(7.65)$ & 0.824 & 98.9 \\
\hline Copper & $1.2 \pm 0.2$ & $1.194 \pm 0.074(6.20)$ & 0.855 & 99.5 \\
\hline Zinc & $0.97 \pm 0.01$ & $0.965 \pm 0.019(1.97)$ & 0.376 & 99.5 \\
\hline Nickel & ------ & ----- & ----- & -------- \\
\hline Cadmium & ----- & ----- & ----- & --------- \\
\hline \multicolumn{5}{|c|}{ CRM of whole blood (mg/L) } \\
\hline Iron & $14.2 \pm 3.24$ & $14.15 \pm 0.76(5.37)$ & 0.935 & 99.6 \\
\hline Copper & $13.9 \pm 2.7$ & $13.85 \pm 0.97(7.00)$ & 0.910 & 99.6 \\
\hline Zinc & $2.27 \pm 0.06$ & $2.24 \pm 0.05(2.23)$ & 0.304 & 98.7 \\
\hline Nickel $^{e}$ & $7.5 \pm 1.8$ & $7.45 \pm 0.56(7.51)$ & 0.106 & 99.3 \\
\hline Cadmium $^{e}$ & $1.2 \pm 0.4$ & $1.185 \pm 0.105(8.86)$ & 0.095 & 98.7 \\
\hline \multicolumn{5}{|c|}{ CRM of human hair $(\mu \mathrm{g} / \mathrm{g})$} \\
\hline Iron & $580.0 \pm 10^{\mathrm{d}}$ & $576.0 \pm 21.0(3.64)$ & 0.657 & 99.3 \\
\hline Copper & $110 \pm 5^{\mathrm{f}}$ & $109.5 \pm 4.33(3.95)$ & 0.838 & 99.5 \\
\hline Zinc & $199 \pm 5$ & $198.5 \pm 10.0(5.04)$ & 0.872 & 99.7 \\
\hline Nickel & $46.0 \pm 1.4^{\mathrm{f}}$ & $45.82 \pm 1.062 .31)$ & 0.559 & 99.6 \\
\hline Cadmium & $0.52 \pm 0.024$ & $0.516 \pm 0.027(5.23)$ & 0.198 & 99.2 \\
\hline
\end{tabular}

Key: $-{ }^{\mathrm{c}} \mathrm{mg} / \mathrm{l},{ }^{\mathrm{d}}$ Informative value, ${ }^{\mathrm{e}} \mu \mathrm{g} / \mathrm{l},{ }^{\mathrm{f}}$ Indicative value, Values in ( ) are \%RSD. $\wedge$ Paired t-test between Certified Value and MWD DF $=5, \mathrm{~T}(\mathrm{critical})$ at $95 \% \mathrm{CI}=2.57, \mathrm{p}<0.50, \$ \%$ recovery was calculated according to: $([\mathrm{MDM}]) /([$ Certified Value $]) \times 100$.

(b)

\begin{tabular}{|c|c|c|c|c|c|c|}
\hline $\begin{array}{l}\text { Added solutions in } \\
\text { micrograms per gram }\end{array}$ & Sputum & $\%$ recovery & Saliva & $\%$ recovery & Nasal Fluid & $\%$ recovery \\
\hline \multicolumn{7}{|c|}{ Zinc $(\mu \mathrm{g} / \mathrm{L})$} \\
\hline 0 & $132 \pm 5.23$ & --- & $357 \pm 6.98$ & --- & $161 \pm 8.05$ & --- \\
\hline 10 & $141.5 \pm 3.85$ & 99.6 & $366.2 \pm 5.00$ & 99.8 & $170.3 \pm 6.84$ & 99.6 \\
\hline 20 & $151.2 \pm 4.05$ & 99.5 & $376.5 \pm 7.15$ & 99.8 & $180.5 \pm 7.92$ & 99.7 \\
\hline 30 & $160.9 \pm 6.02$ & 99.3 & $385.7 \pm 6.33$ & 99.6 & $190.2 \pm 6.91$ & 99.6 \\
\hline \multicolumn{7}{|c|}{ Iron $(\mu \mathrm{g} / \mathrm{L})$} \\
\hline 0 & $1.25 \pm 0.21$ & --- & $0.85 \pm 0.13$ & --- & $1.14 \pm 0.15$ & --- \\
\hline 0.5 & $1.742 \pm 0.15$ & 99.5 & $1.345 \pm 0.11$ & 99.6 & $1.632 \pm 0.09$ & 99.5 \\
\hline 1.0 & $2.241 \pm 0.26$ & 99.6 & $1.842 \pm 0.14$ & 99.6 & $2.135 \pm 0.13$ & 99.8 \\
\hline 2.0 & $3.2395 \pm 0.19$ & 99.7 & $2.838 \pm 0.16$ & 99.6 & $3.129 \pm 0.12$ & 99.6 \\
\hline \multicolumn{7}{|c|}{ Copper $(\mu \mathrm{g} / \mathrm{L})$} \\
\hline 0 & $589 \pm 16.2$ & --- & $162 \pm 7.09$ & --- & $219 \pm 13.7$ & --- \\
\hline 10 & $598.5 \pm 13.5$ & 99.9 & $171.5 \pm 8.01$ & 99.7 & $228.4 \pm 9.91$ & 99.7 \\
\hline 20 & $608.5 \pm 15.6$ & 99.9 & $181.2 \pm 9.65$ & 99.5 & $238.5 \pm 8.66$ & 99.8 \\
\hline 30 & $618.2 \pm 11.9$ & 99.8 & $190.9 \pm 7.95$ & 99.4 & $247.9 \pm 10.5$ & 99.5 \\
\hline
\end{tabular}




\begin{tabular}{|c|c|c|c|c|c|c|}
\hline \multicolumn{7}{|c|}{ Nickel $(\mu \mathrm{g} / \mathrm{L})$} \\
\hline 0 & $0.023 \pm 0.003$ & --- & $4.05 \pm 0.15$ & --- & $0.027 \pm 0.005$ & --- \\
\hline 0.50 & $0.5221 \pm 0.007$ & 99.8 & $4.543 \pm 1.95$ & 99.8 & $0.5262 \pm 0.03$ & 99.8 \\
\hline 1.00 & $1.022 \pm 0.012$ & 99.9 & $5.041 \pm 3.65$ & 99.8 & $1.0261 \pm 0.028$ & 99.9 \\
\hline \multicolumn{7}{|c|}{ Cadmium $(\mu \mathrm{g} / \mathrm{L})$} \\
\hline 0 & $0.25 \pm 0.05$ & --- & $0.034 \pm 0.01$ & --- & $1.31 \pm 0.20$ & --- \\
\hline 0.25 & $0.492 \pm 0.09$ & 98.4 & $0.2835 \pm 0.043$ & 99.8 & $1.555 \pm 0.35$ & 99.6 \\
\hline 0.50 & $0.744 \pm 0.15$ & 99.2 & $0.5334 \pm 0.037$ & 99.8 & $1.802 \pm 0.29$ & 99.5 \\
\hline
\end{tabular}

\section{Reagents and glassware}

Water used during processes was ultra-pure transfused through Millipore (Mili-Q USA). E. Merck, Germany, produces analytical grade chemicals including hydrogen per oxide and nitric acid was used. All the samples were tested for metal contaminations before use. Fluka Kamica (Buchs, Switzerland) certificated $1000 \mathrm{ppm}$ standard solutions of $\mathrm{Cu}, \mathrm{Fe}, \mathrm{Ni}, \mathrm{Zn}$ and $\mathrm{Cd}$ were used. Serial dilution of Working standard (stock) solutions were made using $\mathrm{HNO}_{3}(0.2 \mathrm{~mol} / \mathrm{L})$. The produced solutions were refrigerated at $4^{\circ} \mathrm{C}$ for further analysis in polyethylene bottles. To reach sensitive and selective method, certified reference materials (CRMs) of human hair BCR 397 (Brussels, Belgium), (Germany Munich, Recipe) blood and Clinchek ${ }^{\circledR}$, Control lypholized human serum were bought. Plastic materials and apparatus were dipped in $2 \mathrm{~mol} / \mathrm{L} \mathrm{HNO}_{3}$ for twenty-four hours followed by washing and rinsing with Mili-Q'd water.

\section{Microwave-assisted Acid Digestion Method}

Duplicates of each sample were prepared for elemental analysis with the help of microwave oven-based digestion method. As for the certificated reference materials (serum and blood), six replicate samples were prepared. Digestion was done by mixing $200 \mathrm{mg}$ of hair samples and $0.2 \mathrm{~mL}$ of nasal fluid, serum, sputum and blood sample with $1 \mathrm{~mL}$ of freshly prepared $\mathrm{H}_{2} \mathrm{O}_{2}-\mathrm{HNO}_{3}$ mixture (1:2, $\mathrm{v} / \mathrm{v}$ ) in PTFE flask, for each sample. This mixture flask the placed in MW oven followed by 3 minutes exposed to microwaves at the power of $950 \mathrm{MW}$, until complete sample digestion was achieved. The flask containing digested samples was allowed to reach room temperature and diluted with Mili-Q water to reach final volume mark of $10 \mathrm{~mL}$. These samples were then analyzed for $\mathrm{Cd}$ and $\mathrm{Zn}$ using FAAS and ETAAS, respectively. Same procedure was followed for the preparation of blank samples.

Finally, $\mathrm{Cu}, \mathrm{Fe}$ and $\mathrm{Zn}$ concentrations in standards samples were analyzed by FAAS. The $\mathrm{Cu}, \mathrm{Fe}$ and $\mathrm{Zn}, \mathrm{Cd}$ and $\mathrm{Ni}$ in scalp hair, blood and serum samples of referents and COVID-19 patients were measured through FAAS mode, whilst in the saliva, sputum and nasal fluids of referents and COVID-19 patients were de- 
termined by ETAAS mode.

\section{Data and Statistical Analyses}

Excel X state and Minitab software were used for the statistical analysis of data. The accuracy of analytical method was performed with certified reference materials of Hair BCR 397, Clin check blood and serum samples and spiking the standards of all five metals in a real sample of sputum, saliva and nasal fluid of referent human subjects. The reliability of method was found to be best in accord with certified values of $\mathrm{Cu}, \mathrm{Fe}$ and $\mathrm{Zn}, \mathrm{Cd}$ and $\mathrm{Ni}, 98.7 \%-99.7 \%$ recovery, whilst in spike methods, the \% recovery was found to be in the range of 98.4 99.9 (Table 5(a), Table 5(b)). Samples required less than 5 minutes to be digested fully, slight variation of $(<1 \%-2 \%)$ with respect to mean values of each element was observed with relative standard deviation (RSD) $<2 \%$.

\section{Analytical Figures of Merit}

Calibration was performed with a series of $\mathrm{Cu}, \mathrm{Cd}, \mathrm{Fe}, \mathrm{Ni}$ and $\mathrm{Zn}$ standards. Sensitivity $(\mathrm{m})$ was the slope value obtained by least-square regression analysis of calibration curves based on absorbance signals. The equation $(n=5)$ for the calibration curves was as follows:

$$
\begin{aligned}
& Y=\left(4.35 \times 10^{-3}\right) \mathrm{Cu}+4.25 \times 10^{-4}, r=0.999 \\
& Y=\left(1.06 \times 10^{-4}\right) \mathrm{Cd}+1.25 \times 10^{-5}, r=0.999 \\
& Y=\left(1.18 \times 10^{-3}\right) \mathrm{Fe}+1.25 \times 10^{-4}, r=0.999 \\
& Y=\left(2.09 \times 10^{-4}\right) \mathrm{Ni}+1.68 \times 10^{-5}, r=0.999 \\
& Y=\left(8.09 \times 10^{-3}\right) \mathrm{Zn}+7.60 \times 10^{-4}, r=0.999
\end{aligned}
$$

where $Y$ is the integrated absorbance, $r$ is the regression and the concentration range of $\mathrm{Cu}, \mathrm{Cd}, \mathrm{Fe}, \mathrm{Ni}$ and $\mathrm{Zn}$ for calibration curve reached from the detection limits up to $100 \mu \mathrm{g} / \mathrm{L}$. The limit of detection, equal to $0.005 \mathrm{ng} / \mathrm{mg}, 0.0003$ $\mathrm{ng} / \mathrm{mg}, 0.001 \mathrm{ng} / \mathrm{mg}, 0.001 \mathrm{ng} / \mathrm{mg}$, and $0.005 \mathrm{ng} / \mathrm{mg}$ for $\mathrm{Cu}, \mathrm{Cd}, \mathrm{Fe}, \mathrm{Ni}$ and $\mathrm{Zn}$, respectively, was defined as $3 \mathrm{~s} / \mathrm{m}$, "s" being the standard deviation corresponding to ten blank injections and " $\mathrm{m}$ " the slope of the calibration graph. The quantification limits, defined as $10 \mathrm{~s} / \mathrm{m}$ were calculated as: 0.0013, 0.010, 0.003, 0.003 and $0.014 \mathrm{ng} / \mathrm{mg}$ for $\mathrm{Cd}, \mathrm{Cu}, \mathrm{Fe}, \mathrm{Ni}$ and $\mathrm{Zn}$, respectively.

\section{Results}

Serum cholesterol, HDL, LDL, Triglyceride, Total Albumin, Total protein, Vitamin $\mathrm{D}$ and Hemoglobin were found to be lower in smoker and nonsmoker Tuberculosis (T.B), viral pneumonia, and COVID-19 patients than referents whilst Leucocyte, ESR and CRP were found to be higher in T.B, viral pneumonia, and COVID-19 patients than referents (Table 2).

The mean concentrations with SD for essential trace and toxic elements in biological (serum, scalp hair, saliva, blood, nasal fluid, and sputum) samples are elaborated in Table 6 . The results indicate alterations of the concentrations of essential trace $(\mathrm{Cu}, \mathrm{Fe}, \mathrm{Zn})$ and toxic elements ( $\mathrm{Ni}$ and $\mathrm{Cd}$ ) in biological samples (saliva, blood, nasal fluid, and serum) of smoker and non-smoker COVID-19 patients of both genders. 
Table 6. Elemental concentrations in biological samples of referent and Covid-19 patients.

\begin{tabular}{|c|c|c|c|c|c|c|c|}
\hline Referents/Patients & $\mathrm{NS} / \mathrm{S}$ & Biological samples & Zinc & Iron & Copper & Nickel & Cadmium \\
\hline \multirow{4}{*}{ Referents } & \multirow{2}{*}{ Non smokers } & \multirow{8}{*}{ Scalp hairs $(\mu \mathrm{g} / \mathrm{g})$} & $239 \pm 16.4$ & $41.1 \pm 3.33$ & $15.5 \pm 1.27$ & $4.25 \pm 0.52$ & $1.42 \pm 0.25$ \\
\hline & & & $230-249$ & $40.3-42.3$ & $14.8-16.2$ & $3.97-4.50$ & $1.30-1.55$ \\
\hline & \multirow{2}{*}{ Smokers } & & $207 \pm 19.5$ & $36.4 \pm 2.38$ & $13.9 \pm 0.85$ & $5.15 \pm 0.32$ & $1.47 \pm 0.20$ \\
\hline & & & $195-215$ & $35.0-37.9$ & $13.4-14.3$ & $5.04-5.39$ & $1.36-1.56$ \\
\hline \multirow{4}{*}{ COVID 19 Patients } & \multirow[b]{2}{*}{ Non smokers } & & $124 \pm 16.8$ & $30.4 \pm 0.95$ & $13.2 \pm 1.33$ & $5.95 \pm 0.61$ & $2.89 \pm 0.35$ \\
\hline & & & $115-134$ & $29.8-30.9$ & $12.5-13.9$ & $5.62-6.32$ & $2.72-3.05$ \\
\hline & \multirow{2}{*}{ Smokers } & & $115 \pm 20.7$ & $28.6 \pm 0.82$ & $12.0 \pm 0.68$ & $7.41 \pm 0.45$ & $2.93 \pm 0.30$ \\
\hline & & & $105-126$ & $28.4-29.1$ & $11.6-12.4$ & $7.15-7.54$ & $2.78-3.10$ \\
\hline \multirow{4}{*}{ Referents } & \multirow{2}{*}{ Non smokers } & & $5.90 \pm 0.22$ & $483 \pm 18.5$ & $1.09 \pm 0.05$ & $1.93 \pm 0.32$ & $3.57 \pm 0.39$ \\
\hline & & & $5.83-5.97$ & $474-495$ & $1.04-1.12$ & $1.76-2.10$ & $3.39-3.74$ \\
\hline & \multirow{2}{*}{ Smokers } & & $5.54 \pm 0.20$ & $443 \pm 16.2$ & $0.97 \pm 0.05$ & $2.10 \pm 0.35$ & $3.62 \pm 0.42$ \\
\hline & & Blood (mg/L) & $5.47-5.65$ & $435-451$ & $0.92-1.00$ & $1.98-2.23$ & $3.40-3.83$ \\
\hline \multirow{4}{*}{ COVID 19 Patients } & \multirow{2}{*}{ Non smokers } & $(\mu \mathrm{g} / \mathrm{L})$ for $\mathrm{Ni} \& \mathrm{Cd}$ & $4.15 \pm 0.20$ & $395 \pm 12.9$ & $0.79 \pm 0.06$ & $3.29 \pm 0.41$ & $6.75 \pm 0.32$ \\
\hline & & & $4.03-4.26$ & $389-402$ & $0.77-0.83$ & $3.02-3.45$ & $6.59-6.92$ \\
\hline & \multirow{2}{*}{ Smokers } & & $3.79 \pm 0.15$ & $339 \pm 11.4$ & $0.68 \pm 0.07$ & $3.51 \pm 0.30$ & $6.89 \pm 0.28$ \\
\hline & & & $3.70-3.89$ & $333-345$ & $0.65-0.72$ & $3.31-4.01$ & $6.75-7.05$ \\
\hline \multirow{4}{*}{ Referents } & \multirow{2}{*}{ Non smokers } & & $1.19 \pm 0.19$ & $3.89 \pm 0.65$ & $0.80 \pm 0.11$ & $115 \pm 14.1$ & $0.033 \pm 0.004$ \\
\hline & & & $1.10-1.28$ & $3.59-4.19$ & $0.75-0.84$ & $107-122$ & $0.032-0.034$ \\
\hline & \multirow{2}{*}{ Smokers } & & $1.12 \pm 0.15$ & $3.56 \pm 0.52$ & $0.72 \pm 0.07$ & $122 \pm 9.52$ & $0.062 \pm 0.006$ \\
\hline & & Serum $(\mathrm{mg} / \mathrm{L})$ & $1.06-1.17$ & $3.30-3.82$ & $0.69-0.75$ & $115-127$ & $0.061-0.064$ \\
\hline \multirow{4}{*}{ COVID 19 Patients } & \multirow{2}{*}{ Non smokers } & $(\mu \mathrm{g} / \mathrm{L})$ for $\mathrm{Ni} \& \mathrm{Cd}$ & $0.68 \pm 0.08$ & $2.48 \pm 0.20$ & $0.57 \pm 0.10$ & $228 \pm 20.2$ & $0.035 \pm 0.002$ \\
\hline & & & $0.63-073$ & $2.36-2.59$ & $0.52-0.63$ & $214-235$ & $0.034-0.036$ \\
\hline & \multirow{2}{*}{ Smokers } & & $0.52 \pm 0.06$ & $2.15 \pm 0.16$ & $0.50 \pm 0.04$ & $299 \pm 12.2$ & $0.065 \pm 0.008$ \\
\hline & & & $0.50-0.56$ & $2.07-2.24$ & $0.48-0.53$ & $289-309$ & $0.063-0.067$ \\
\hline \multirow{4}{*}{ Referents } & \multirow{2}{*}{ Non smokers } & & $365 \pm 13.5$ & $1.38 \pm 0.25$ & $637 \pm 105$ & $0.024 \pm 0.004$ & $0.27 \pm 0.04$ \\
\hline & & & $357-372$ & $1.25-1.52$ & $589-702$ & $0.023-0.024$ & $0.25-0.29$ \\
\hline & & & $335 \pm 12.4$ & $1.27 \pm 0.20$ & $598 \pm 98.5$ & $0.026 \pm 0.003$ & $0.29 \pm 0.05$ \\
\hline & Smokers & & $327-340$ & $1.20-1.34$ & $549-645$ & $0.026-0.027$ & $0.26-0.32$ \\
\hline & Non & L) & $162 \pm 18.5$ & $1.12 \pm 0.22$ & $468 \pm 85.2$ & $0.058 \pm 0.004$ & $0.76 \pm 0.12$ \\
\hline & Non smokers & & $151-170$ & $1.01-1.23$ & $445-495$ & $0.057-0.061$ & $0.69-0.81$ \\
\hline tients & Smolrons & & $151 \pm 7.39$ & $0.95 \pm 0.15$ & $445 \pm 65.3$ & $0.071 \pm 0.007$ & $0.82 \pm 0.05$ \\
\hline & Smokers & & $147-154$ & $0.89-1.03$ & $419-479$ & $0.065-0.074$ & $0.79-0.85$ \\
\hline & Nom & & $138 \pm 12.7$ & $0.89 \pm 0.09$ & $169 \pm 13.5$ & $4.15 \pm 0.25$ & $0.034 \pm 0.005$ \\
\hline & Non & & $132-145$ & $0.85-0.91$ & $162-175$ & $4.05-4.29$ & $0.0338-0.0352$ \\
\hline $\mathbf{K}$ & Smoters & & $126 \pm 9.85$ & $0.83 \pm 0.05$ & $96.5 \pm 10.5$ & $4.38 \pm 0.19$ & $0.036 \pm 0.004$ \\
\hline & Smokers & & $120-132$ & $0.81-0.85$ & $90.5-102$ & $4.28-4.49$ & $0.034-0.038$ \\
\hline & & ) & $72.4 \pm 9.52$ & $0.65 \pm 0.08$ & $152 \pm 11.9$ & $8.58 \pm 0.19$ & $0.078 \pm 0.008$ \\
\hline 0 & Non smokers & & $66.9-77.9$ & $0.59-0.68$ & $146-158$ & $8.47-8.70$ & $0.077-0.079$ \\
\hline COVID & & & $55.7 \pm 5.92$ & $0.57 \pm 0.06$ & $82.6 \pm 9.57$ & $8.65 \pm 0.22$ & $0.080 \pm 0.004$ \\
\hline & Smokers & & $52.9-58.0$ & $0.54-0.60$ & $75.6-87.9$ & $8.55-8.76$ & $0.078-0.082$ \\
\hline & & & $167 \pm 20.3$ & $1.21 \pm 0.14$ & $227 \pm 19.5$ & $0.028 \pm 0.003$ & $1.40 \pm 0.19$ \\
\hline & Non & & $161-173$ & $1.14-1.29$ & $219-240$ & $0.027-0.031$ & $1.31-1.50$ \\
\hline $\mathrm{Ke}$ & & & $160 \pm 17.7$ & $1.12 \pm 0.12$ & $205 \pm 8.55$ & $0.035 \pm 0.005$ & $1.49 \pm 0.23$ \\
\hline & Smokers & & $153-168$ & $1.05-1.18$ & $200-212$ & $0.034-0.036$ & $1.35-1.62$ \\
\hline & & Nasal Fluid $(\mu \mathrm{g} / \mathrm{L})$ & $92.6 \pm 9.45$ & $0.93 \pm 0.06$ & $125 \pm 11.5$ & $0.074 \pm 0.005$ & $2.75 \pm 0.39$ \\
\hline & Non smokers & & $87.2-98.0$ & $0.90-0.97$ & $119-131$ & $0.069-0.075$ & $2.57-2.97$ \\
\hline $\mathrm{CO}$ & $\mathrm{Smol}^{-1}$ & & $82.9 \pm 7.20$ & $0.82 \pm 0.04$ & $119 \pm 9.65$ & $0.097 \pm 0.009$ & $2.85 \pm 0.25$ \\
\hline & Smokers & & $78.6-86.3$ & $0.78-0.84$ & $114-125$ & $0.089-0.099$ & $2.72-2.99$ \\
\hline
\end{tabular}


The Zn contents in scalp hair, blood, serum, sputum, saliva and nasal fluid samples of male nonsmoker and smoker COVID-19 patients was found to be lower at 95\% confidence interval $\{[\mathrm{CI} 116-132] \mu \mathrm{g} / \mathrm{g},[4.05-4.25] \mathrm{mg} / \mathrm{L},[\mathrm{CI}$ 0.64 - 0.73] mg/L, [150 - 165] $\mu \mathrm{g} / \mathrm{L},[\mathrm{CI} 67.5$ - 78.0] $\mu \mathrm{g} / \mathrm{L}$, and [86.7 - 98.5] $\mu \mathrm{g} / \mathrm{L}\}$ and $\{[C I 106-125] \mu \mathrm{g} / \mathrm{g},[3.72$ - 3.87] $\mathrm{mg} / \mathrm{L}$, [CI $0.49-0.55] \mathrm{mg} / \mathrm{L}$, [CI 145 - 152] $\mu \mathrm{g} / \mathrm{L},[\mathrm{CI} 52.2$ - 58.2] $\mu \mathrm{g} / \mathrm{L}$, and [CI 136 - 145] $\mu \mathrm{g} / \mathrm{L}$ \}, respectively, as compared to $\mathrm{Zn}$ in scalp hair, blood, serum, sputum, saliva and nasal fluid samples of male smoker and nonsmoker referents $\{[\mathrm{CI} 231$ - 246] $\mu \mathrm{g} / \mathrm{g}$, [CI $5.79-6.10] \mathrm{mg} / \mathrm{L}$, [CI 1.08 - 1.30] mg/l, [(CI 358 - 372] $\mu \mathrm{g} / \mathrm{L}$, [CI 133 - 146] $\mu \mathrm{g} / \mathrm{L}$, and [CI 157 - 175] $\mu \mathrm{g} / \mathrm{L})\}$ and $\{([\mathrm{CI} 192-215] \mu \mathrm{g} / \mathrm{g},[\mathrm{CI} 5.43-5.62] \mathrm{mg} / \mathrm{L},[\mathrm{CI} 1.04-1.20] \mathrm{mg} / \mathrm{L}$, [CI 325 - 338] $\mu \mathrm{g} / \mathrm{L}$, [CI 119 - 131] $\mu \mathrm{g} / \mathrm{L}$, and [CI 152 - 169] $\mu \mathrm{g} / \mathrm{L}$, respectively (Table 6). The $\mathrm{Zn}$ concentration were found to be significantly lower in the biological samples of Covid-19, Tuberculosis and viral pneumonia patients as compare to referents $(\mathrm{p}<0.001)$. Whilst the $\mathrm{Zn}$ levels in the biological samples of Tuberculosis and viral pneumonia patients were higher than Covid-19 patients, difference was not significant ( $p>0.032$ ) (Table 7).

Table 7. Elemental concentrations in biological samples of referent and pulmonary respiratory disease patients.

\begin{tabular}{|c|c|c|c|c|c|c|}
\hline \multirow{2}{*}{ Biological specimens } & \multicolumn{3}{|c|}{ Non smokers } & \multicolumn{3}{|c|}{ smokers } \\
\hline & Referents & T.B patients & Pneumonia & Referents & T.B patients & Pneumonia \\
\hline \multicolumn{7}{|c|}{ Zinc } \\
\hline \multirow{2}{*}{ Scalp hairs $(\mu \mathrm{g} / \mathrm{g})$} & $239 \pm 16.4$ & $145 \pm 15.2$ & $134 \pm 9.35$ & $207 \pm 19.5$ & $143 \pm 8.02$ & $125 \pm 7.92$ \\
\hline & $230-249$ & $137-152$ & $128-137$ & $195-215$ & $139-146$ & $121-129$ \\
\hline \multirow{2}{*}{ Blood (mg/L) } & $5.90 \pm 0.22$ & $4.60 \pm 0.31$ & $4.32 \pm 0.22$ & $5.54 \pm 0.20$ & $4.30 \pm 0.24$ & $4.10 \pm 0.20$ \\
\hline & $5.83-5.97$ & $4.50-4.75$ & $4.25-4.41$ & $5.47-5.65$ & $4.19-4.42$ & $3.99-4.20$ \\
\hline \multirow{2}{*}{$\operatorname{Serum}(\mathrm{mg} / \mathrm{L})$} & $1.19 \pm 0.19$ & $0.96 \pm 0.09$ & $0.81 \pm 0.10$ & $1.12 \pm 0.15$ & $0.85 \pm 0.09$ & $0.70 \pm 0.05$ \\
\hline & $1.10-1.28$ & $0.90-1.02$ & $0.75-0.85$ & $1.06-1.17$ & $0.79-0.89$ & $0.67-0.74$ \\
\hline \multirow{2}{*}{ Sputum $(\mu \mathrm{g} / \mathrm{L})$} & $365 \pm 13.5$ & $230 \pm 7.44$ & $199 \pm 9.90$ & $335 \pm 12.4$ & $215 \pm 7.32$ & $182 \pm 7.52$ \\
\hline & $357-372$ & $226-234$ & $195-205$ & $327-340$ & $212-219$ & $178-185$ \\
\hline \multirow{2}{*}{ Saliva $(\mu \mathrm{g} / \mathrm{L})$} & $138 \pm 12.7$ & $106 \pm 12.9$ & $90.0 \pm 7.41$ & $126 \pm 9.85$ & $89.9 \pm 5.79$ & $72.5 \pm 7.75$ \\
\hline & $132-145$ & $99.2-113$ & $86.7-94.0$ & $120-132$ & $87.3-93.0$ & $68.9-75.2$ \\
\hline \multirow{2}{*}{ Nasal Fluid $(\mu \mathrm{g} / \mathrm{L})$} & $167 \pm 20.3$ & $115 \pm 7.66$ & $109 \pm 7.62$ & $160 \pm 17.7$ & $110 \pm 5.90$ & $96.0 \pm 6.22$ \\
\hline & $161-173$ & $112-119$ & $105-114$ & $153-168$ & $107-113$ & $92.9-99.2$ \\
\hline \multicolumn{7}{|c|}{ Iron } \\
\hline \multirow{2}{*}{ Scalp hairs $(\mu \mathrm{g} / \mathrm{g})$} & $41.1 \pm 3.33$ & $35.5 \pm 1.91$ & $33.7 \pm 1.60$ & $36.4 \pm 2.38$ & $33.5 \pm 0.95$ & $31.7 \pm 0.80$ \\
\hline & $40.3-42.3$ & $32.9-36.4$ & $32.8-34.9$ & $35.0-37.9$ & $32.9-33.9$ & $31.2-32.3$ \\
\hline \multirow{2}{*}{ Blood (mg/L) } & $483 \pm 18.5$ & $425 \pm 13.2$ & $415 \pm 9.52$ & $443 \pm 16.2$ & $399 \pm 8.41$ & $369 \pm 7.50$ \\
\hline & $474-495$ & $419-433$ & $409-419$ & $435-451$ & $394-403$ & $364-374$ \\
\hline \multirow{2}{*}{$\operatorname{Serum}(\mathrm{mg} / \mathrm{L})$} & $3.89 \pm 0.65$ & $2.92 \pm 0.41$ & $2.55 \pm 0.35$ & $3.56 \pm 0.52$ & $2.69 \pm 0.39$ & $2.42 \pm 0.25$ \\
\hline & $3.59-4.19$ & $2.73-3.12$ & $2.41-2.72$ & $3.30-3.82$ & $2.50-2.92$ & $2.29-2.55$ \\
\hline \multirow{2}{*}{ Sputum $(\mu \mathrm{g} / \mathrm{L})$} & $1.38 \pm 0.25$ & $1.29 \pm 0.05$ & $1.20 \pm 0.05$ & $1.27 \pm 0.20$ & $1.13 \pm 0.05$ & $1.05 \pm 0.05$ \\
\hline & $1.25-1.52$ & $1.21-1.32$ & $1.16-1.24$ & $1.20-1.34$ & $1.09-1.16$ & $1.02-1.04$ \\
\hline \multirow{2}{*}{ Saliva $(\mu \mathrm{g} / \mathrm{L})$} & $0.89 \pm 0.09$ & $0.72 \pm 0.05$ & $0.65 \pm 0.06$ & $0.83 \pm 0.05$ & $0.67 \pm 0.05$ & $0.59 \pm 0.04$ \\
\hline & $0.85-0.91$ & $0.70-0.75$ & $0.63-0.68$ & $0.81-0.85$ & $0.65-0.70$ & $0.57-0.62$ \\
\hline \multirow{2}{*}{ Nasal Fluid $(\mu \mathrm{g} / \mathrm{L})$} & $1.21 \pm 0.14$ & $1.12 \pm 0.02$ & $1.05 \pm 0.06$ & $1.12 \pm 0.12$ & $1.00 \pm 0.08$ & $0.97 \pm 0.05$ \\
\hline & $1.14-1.29$ & $1.09-1.13$ & $1.02-1.08$ & $1.05-1.18$ & $0.97-1.03$ & $0.95-0.99$ \\
\hline
\end{tabular}




\begin{tabular}{|c|c|c|c|c|c|c|}
\hline \multicolumn{7}{|c|}{ Copper } \\
\hline \multirow{2}{*}{ Scalp hairs $(\mu g / g)$} & $15.5 \pm 1.27$ & $14.2 \pm 0.48$ & $13.7 \pm 0.65$ & $13.9 \pm 0.85$ & $12.3 \pm 0.30$ & $12.0 \pm 0.24$ \\
\hline & $14.8-16.2$ & $13.9-14.3$ & $13.5-13.9$ & $13.4-14.3$ & $12.1-12.5$ & $11.8-12.2$ \\
\hline \multirow{2}{*}{ Blood (mg/L) } & $1.09 \pm 0.05$ & $0.98 \pm 0.06$ & $0.85 \pm 0.07$ & $0.97 \pm 0.05$ & $0.82 \pm 0.05$ & $0.75 \pm 0.05$ \\
\hline & $1.04-1.12$ & $0.95-1.03$ & $0.82-0.87$ & $0.92-1.00$ & $0.80-0.85$ & $0.72-0.77$ \\
\hline \multirow{2}{*}{ Serum(mg/L) } & $0.80 \pm 0.11$ & $0.72 \pm 0.05$ & $0.60 \pm 0.05$ & $0.72 \pm 0.07$ & $0.63 \pm 0.04$ & $0.59 \pm 0.05$ \\
\hline & $0.75-0.84$ & $0.69-0.73$ & $0.58-0.62$ & $0.69-0.75$ & $0.51-0.65$ & $0.57-0.62$ \\
\hline \multirow{2}{*}{ Sputum $(\mu \mathrm{g} / \mathrm{L})$} & $637 \pm 105$ & $565 \pm 60.2$ & $509 \pm 29.4$ & $598 \pm 98.5$ & $538 \pm 40.5$ & $479 \pm 26.0$ \\
\hline & $589-702$ & $530-595$ & $485-526$ & $549-645$ & $514-555$ & $465-495$ \\
\hline \multirow{2}{*}{ Saliva $(\mu \mathrm{g} / \mathrm{L})$} & $169 \pm 13.5$ & $145 \pm 9.40$ & $115 \pm 7.51$ & $152 \pm 11.9$ & $132 \pm 9.50$ & $114 \pm 7.35$ \\
\hline & $162-175$ & $139-149$ & $110-118$ & $146-158$ & $128-137$ & $109-117$ \\
\hline \multirow{2}{*}{ Nasal Fluid $(\mu \mathrm{g} / \mathrm{L})$} & $227 \pm 19.5$ & $174 \pm 6.08$ & $145 \pm 5.62$ & $205 \pm 8.55$ & $167 \pm 8.95$ & $139 \pm 6.02$ \\
\hline & $219-240$ & $172-178$ & $142-149$ & $200-212$ & $162-172$ & $136-141$ \\
\hline \multicolumn{7}{|c|}{ Nickel } \\
\hline \multirow{2}{*}{ Scalp hairs $(\mu g / g)$} & $4.25 \pm 0.52$ & $5.65 \pm 0.50$ & $5.85 \pm 0.42$ & $5.15 \pm 0.32$ & $5.85 \pm 0.32$ & $6.43 \pm 0.47$ \\
\hline & $3.97-4.50$ & $5.42-5.93$ & $5.57-6.01$ & $5.04-5.39$ & $5.70-6.04$ & $6.23-6.70$ \\
\hline \multirow{2}{*}{ Blood $(\mu \mathrm{g} / \mathrm{L})$} & $1.93 \pm 0.32$ & $2.45 \pm 0.22$ & $2.82 \pm 0.35$ & $2.10 \pm 0.35$ & $2.59 \pm 0.20$ & $3.05 \pm 0.21$ \\
\hline & $1.76-2.10$ & $2.37-2.57$ & $2.67-3.00$ & $1.98-2.23$ & $2.47-2.68$ & $2.92-3.12$ \\
\hline \multirow{2}{*}{ Serum $(\mu g / L)$} & $115 \pm 14.1$ & $155 \pm 9.32$ & $182 \pm 9.95$ & $122 \pm 9.52$ & $189 \pm 14.5$ & $243 \pm 19.6$ \\
\hline & $107-122$ & $150-162$ & $178-187$ & $115-127$ & $182-195$ & $234-255$ \\
\hline \multirow{2}{*}{ Sputum $(\mu \mathrm{g} / \mathrm{L})$} & $0.024 \pm 0.004$ & $0.034 \pm 0.003$ & $0.045 \pm 0.004$ & $0.026 \pm 0.003$ & $0.042 \pm 0.003$ & $0.060 \pm 0.006$ \\
\hline & $0.023-0.024$ & $0.031-0.035$ & $0.043-0.046$ & $0.026-0.027$ & $0.040-0.044$ & $0.057-0.062$ \\
\hline Saliva $(\mu \mathrm{g} / \mathrm{L})$ & $4.15 \pm 0.25$ & $5.95 \pm 0.50$ & $7.27 \pm 0.42$ & $4.38 \pm 0.19$ & $6.36 \pm 0.32$ & $7.80 \pm 0.26$ \\
\hline Nasal Fluid $(\mu \mathrm{g} / \mathrm{L})$ & $0.027-0.031$ & $0.037-0.041$ & $0.054-0.058$ & $0.034-0.036$ & $0.046-0.050$ & $0.071-0.074$ \\
\hline \multicolumn{7}{|c|}{ Cadmium } \\
\hline \multirow{2}{*}{ Scalp hairs $(\mu \mathrm{g} / \mathrm{g})$} & $1.42 \pm 0.25$ & $1.75 \pm 0.32$ & $2.452 \pm 0.35$ & $1.47 \pm 0.20$ & $1.95 \pm 0.20$ & $2.64 \pm 0.49$ \\
\hline & $1.30-1.55$ & $1.65-1.97$ & $1.24-2.60$ & $1.36-1.56$ & $1.86-2.07$ & $2.49-2.79$ \\
\hline \multirow{2}{*}{ Blood $(\mu \mathrm{g} / \mathrm{L})$} & $3.57 \pm 0.39$ & $4.95 \pm 0.40$ & $5.92 \pm 0.35$ & $3.62 \pm 0.42$ & $5.09 \pm 0.42$ & $6.19 \pm 0.40$ \\
\hline & $3.39-3.74$ & $4.79-5.18$ & $5.70-6.12$ & $3.40-3.83$ & $4.81-5.30$ & $6.95-6.30$ \\
\hline \multirow{2}{*}{ Serum $(\mu g / L)$} & $0.033 \pm 0.004$ & $0.045 \pm 0.003$ & $0.056 \pm 0.004$ & $0.035 \pm 0.002$ & $0.048 \pm 0.005$ & $0.062 \pm 0.007$ \\
\hline & $0.032-0.034$ & $0.043-0.047$ & $0.054-0.059$ & $0.034-0.036$ & $0.046-0.050$ & $0.057-0.063$ \\
\hline \multirow{2}{*}{ Sputum $(\mu \mathrm{g} / \mathrm{L})$} & $0.27 \pm 0.04$ & $0.48 \pm 0.09$ & $0.64 \pm 0.06$ & $0.29 \pm 0.05$ & $0.52 \pm 0.06$ & $0.69 \pm 0.05$ \\
\hline & $0.25-0.29$ & $0.42-0.52$ & $0.59-0.67$ & $0.26-0.32$ & $0.49-0.55$ & $0.65-0.71$ \\
\hline \multirow{2}{*}{ Saliva $(\mu \mathrm{g} / \mathrm{L})$} & $0.034 \pm 0.005$ & $0.053 \pm 0.005$ & $0.066 \pm 0.005$ & $0.036 \pm 0.004$ & $0.060 \pm 0.004$ & $0.073 \pm 0.005$ \\
\hline & $0.0338-0.0352$ & $0.050-0.055$ & $0.063-0.068$ & $0.034-0.038$ & $0.058-0.061$ & $0.069-0.074$ \\
\hline \multirow{2}{*}{ Nasal Fluid $(\mu \mathrm{g} / \mathrm{L})$} & $1.40 \pm 0.19$ & $2.29 \pm 0.25$ & $2.57 \pm 0.40$ & $1.49 \pm 0.23$ & $2.44 \pm 0.31$ & $2.73 \pm 0.34$ \\
\hline & $1.31-1.50$ & $2.15-2.39$ & $2.36-2.74$ & $1.35-1.62$ & $2.29-2.57$ & $2.58-2.86$ \\
\hline
\end{tabular}

The Fe contents in scalp hair, blood, serum, sputum, saliva and nasal fluid samples of male nonsmoker and smoker COVID-19 patients was found to be lower at 95\% confidence interval $\{[\mathrm{CI} 37.8$ - 40.5] $\mu \mathrm{g} / \mathrm{g}$, [387 - 400] $\mathrm{mg} / \mathrm{L}$, [CI 2.38 - 2.57] $\mathrm{mg} / \mathrm{L},[1.03-1.25] \mu \mathrm{g} / \mathrm{L}$, [CI 0.60 - 0.67] $\mu \mathrm{g} / \mathrm{L}$, and [CI $0.89-0.95$ ] $\mu \mathrm{g} / \mathrm{L})\}$ and $\{([\mathrm{CI} 30.8-33.0] \mu \mathrm{g} / \mathrm{g},[334-346] \mathrm{mg} / \mathrm{L}$, [CI $2.08-2.25] \mathrm{mg} / \mathrm{L},[\mathrm{CI}$ $0.87-1.02$ ] $\mu \mathrm{g} / \mathrm{L}$, [CI $0.53-0.59$ ] $\mu \mathrm{g} / \mathrm{L}$, and [CI $0.79-0.84$ ] $\mu \mathrm{g} / \mathrm{L}\}$, respectively, 
than Fe in scalp hair, blood, serum, sputum, saliva and nasal fluid samples of male smoker and nonsmoker referents $\{[C I 39.6$ - 41.9] $\mu \mathrm{g} / \mathrm{g}$, [CI 475 - 492] $\mathrm{mg} / \mathrm{L}$, [CI 3.57 - 4.22] mg/L, [(CI 1.27 - 1.50] $\mu \mathrm{g} / \mathrm{L}$, [CI 0.86 - 0.92] $\mu \mathrm{g} / \mathrm{L}$, and [CI 1.12 - 1.27] $\mu \mathrm{g} / \mathrm{L}\}$ and $\{[C I 34.9-38.0] \mu \mathrm{g} / \mathrm{g}$, [CI 436 - 452] $\mathrm{mg} / \mathrm{L}$, [CI $3.32-3.85$ ] $\mathrm{mg} / \mathrm{L},[\mathrm{CI} 1.18-1.36] \mu \mathrm{g} / \mathrm{L}$, [CI $0.80-0.84] \mu \mathrm{g} / \mathrm{L}$, and [CI $1.06-1.17] \mu \mathrm{g} / \mathrm{L}\}$, respectively (Table 6). The Fe concentration were found to be less significantly lower in the biological samples of Covid-19, Tuberculosis and viral pneumonia patients as compare to referents ( $\mathrm{p}<0.015)$. Whilst the Fe levels in the biological samples of Tuberculosis and viral pneumonia patients were higher than Covid19 patients, difference was not significant $(\mathrm{p}>0.041)$ (Table 7).

The $\mathrm{Cu}$ contents in scalp hair, blood, serum, sputum, saliva and nasal fluid samples of male nonsmoker and smoker COVID-19 patients was found to be lower at $95 \%$ confidence interval $\{[\mathrm{CI} 12.5-13.8] \mu \mathrm{g} / \mathrm{g}$, [0.75.0.83] $\mathrm{mg} / \mathrm{L}$, [CI $0.51-0.61] \mathrm{mg} / \mathrm{L},[449$ - 498] $\mu \mathrm{g} / \mathrm{l},[\mathrm{CI} 91.0$ - 101] $\mu \mathrm{g} / \mathrm{L}$, and [119 - 132] $\mu \mathrm{g} / \mathrm{L}\}$ and $\{[C I 11.7-12.3] \mu \mathrm{g} / \mathrm{g},[0.66-0.70] \mathrm{mg} / \mathrm{L},[\mathrm{CI} 0.47-0.52] \mathrm{mg} / \mathrm{L},[\mathrm{CI} 421$ 482] $\mu \mathrm{g} / \mathrm{L},[\mathrm{CI} 76.0$ - 88.2] $\mu \mathrm{g} / \mathrm{L}$, and [CI 115 - 124] $\mu \mathrm{g} / \mathrm{L}\}$, respectively, as compared to $\mathrm{Cu}$ in scalp hair, blood, serum, sputum, saliva and nasal fluid samples of male smoker and nonsmoker referents $\{[C I 14.7-16.3] \mu \mathrm{g} / \mathrm{g},[1.02-1.12]$ $\mathrm{mg} / \mathrm{L},[\mathrm{CI} 0.76$ - 0.85] mg/L, [595 - 710] $\mu \mathrm{g} / \mathrm{L}$, [CI 163 - 178] $\mu \mathrm{g} / \mathrm{L}$, and [220 $238] \mu \mathrm{g} / \mathrm{L}))\}$ and $\{([\mathrm{CI} 13.3-14.5] \mu \mathrm{g} / \mathrm{g}$, [CI $0.93-0.99] \mathrm{mg} / \mathrm{L}$, [CI $0.68-0.73$ ] $\mathrm{mg} / \mathrm{L}$, [CI 550 - 640] $\mu \mathrm{g} / \mathrm{L}$, [CI 145 - 159] $\mu \mathrm{g} / \mathrm{L}$, and [CI 201 - 213] $\mu \mathrm{g} / \mathrm{L}\}$, respectively (Table 6). The $\mathrm{Cu}$ concentration were found to be less significantly lower in the biological samples of Covid-19, Tuberculosis and viral pneumonia patients as compare to referents $(\mathrm{p}<0.019)$. Whilst the $\mathrm{Cu}$ levels in the biological samples of Tuberculosis and viral pneumonia patients were higher than Covid19 patients, difference was not significant ( $p>0.037$ ) (supplementary Table 2).

The concentrations of $\mathrm{Ni}$ in biological samples of biological (scalp hair, blood, serum, sputum, saliva and nasal fluid) samples of male nonsmoker and smoker COVID - 19 patients were significantly higher at 95\% C.I. \{[CI: 5.55 - 6.27] $\mu \mathrm{g} / \mathrm{g}$, [CI: $3.02-3.40] \mu \mathrm{g} / \mathrm{L}$, [CI: $210-240] \mu \mathrm{g} / \mathrm{L}$, [CI $0.055-0.065] \mu \mathrm{g} / \mathrm{L}$, [CI $8.40-$ 9.07] $\mu \mathrm{g} / \mathrm{L}$ and [CI $0.065-0.078] \mu \mathrm{g} / \mathrm{L}\}$ and $\{[C I 7.12-7.62] \mu \mathrm{g} / \mathrm{g}$, [CI $3.33-$ 4.05] $\mu \mathrm{g} / \mathrm{L},[\mathrm{CI} 285-310] \mu \mathrm{g} / \mathrm{L},[\mathrm{CI} 0.060$ - 0.064] $\mu \mathrm{g} / \mathrm{L},[\mathrm{CI} 8.52-8.71] \mu \mathrm{g} / \mathrm{L}$ and [CI $0.0848-0.095] \mu \mathrm{g} / \mathrm{L}\}$ compared with those in male healthy nonsmokers and smokers subjects $\{[\mathrm{CI}: 3.90$ - 4.65] $\mu \mathrm{g} / \mathrm{g}$, [CI: 1.75 - 2.05] $\mu \mathrm{g} / \mathrm{L}$, [CI: 110 - 130] $\mu \mathrm{g} / \mathrm{L},[\mathrm{CI} 0.023-0.025] \mu \mathrm{g} / \mathrm{L},[\mathrm{CI} 4.10-4.32] \mu \mathrm{g} / \mathrm{L}$ and [CI $0.025-0.030] \mu \mathrm{g} / \mathrm{L}$ ) and $\{([$ CI $5.05-5.39] \mu \mathrm{g} / \mathrm{g}$, [CI 1.95 - 2.20] $\mu \mathrm{g} / \mathrm{L}$, [CI 112 - 124] $\mu \mathrm{g} / \mathrm{L}$, [CI $0.025-$ $0.028] \mu \mathrm{g} / \mathrm{L},[\mathrm{CI} 4.25-4.48] \mu \mathrm{g} / \mathrm{L}$ and [CI $0.033-0.037] \mu \mathrm{g} / \mathrm{L}\}(\mathrm{p}<0.01)$. Same trend was seen in female (Table 6). The concentrations of Cd in biological samples of biological (scalp hair, blood, serum, sputum, saliva and nasal fluid) samples of male nonsmoker and smoker COVID-19 patients were significantly higher compared with those in male healthy nonsmokers and smokers subjects. The toxic elemental levels ( $\mathrm{Ni}$ and $\mathrm{Cd}$ ) were found to be significantly higher in Covid-19, Tuberculosis and viral pneumonia patients as compare to referents ( $\mathrm{p}$ 
$<0.001)$. Whilst the Cd and Ni levels in the biological samples of COVID-19 patients were higher than Tuberculosis and viral pneumonia patients, difference was not significant ( $\mathrm{p}>0.065$ ) (Table 7).

Independent student $\mathrm{t}$-test was used to compare the mean values between smoker and non smoker COVID-19 patients and referent subjects.

\section{Discussion}

In Pakistan, the first corona case was reported on $26^{\text {th }}$ Feburary 2020. At this time, covid 19 is a pandemic disease all over the world. The aim of this study is to estimate the essential trace $(\mathrm{Cu}, \mathrm{Fe}$ and $\mathrm{Zn})$ and toxic elemental level in biological samples of Covid 19 patients and controls with smoking and nonsmoking habits in urban areas of Sindh, Pakistan (Hyderabad).

Although it is unclear whether declined serum HDL-cholesterol in COVID-19 infection shares the same mechanism as HIV-1 infection, HDL particles and cholesterol were indicated to be closely related to virus infection. The studies in vitro showed that cholesterol on lipid rafts was proved to be required for the early stage of SARS-CoV replication and during the binding stage of SARS-CoV entering host cells [14]. Furthermore, HDL generally is an anti-inflammatory lipoprotein [15]. However, inflammation was reported to leads to structural alterations of HDL particles and caused the accumulation of the acute phase protein serum amyloid A (SAA) within the protein moiety of HDL [16]. Furthermore, the decrease in serum albumin levels might result from mild diarrhea following the onset of the disease [16]. Currently, COVID-19 infection-associated dyslipidemia had been reported in several clinical studies [17] [18] [19], however, the underlying mechanism of cholesterol metabolism in COVID-19 infection is still unknown. Vitamin D has been suggested as possibly protective of COVID-19 infection [20] [21] and if so, could plausibly play a role in ethnic variations in COVID-19 infection.

In primary outcome, low levels of zinc, copper, and iron were reported in biological samples of COVID 19 patients as compared to referent subjects. While in the secondary outcome, we also determined $\mathrm{Zn}$ level in biological samples of pulmonary Tuberculosis and viral pneumonia. But in COVID-19 patients, Zn level was found to be lower than Tuberculosis and viral pneumonia patients.

Zinc is associated with different cell forms and has an assortment of immediate and aberrant antiviral properties. It was exhibited that $\mathrm{Zn}$ inadequacy is related to diminished counter acting agent creation, influenced capacity of the intrinsic invulnerable framework (e.g., low normal executioner cell movement), diminished cytokine creation by monocytes, and the chemotaxis and oxidative eruption of neutrophil granulocytes [22]. It likewise results in thymic decay, modified thymic hormones creation, lymphopenia, and damaged cell and counter acting agent interceded reactions that lead to expanded rates and span of disease. Specifically, $\mathrm{Zn}$ lack diminishes the quantity of fringe and thymic T cells, their multiplication in light of phytohemagglutinin, and the elements of $\mathrm{T}$ part- 
ners and cytotoxic T cells. What's more, $\mathrm{Zn}$ inadequacy acts in a roundabout way by decreasing the degrees of dynamic serum thymulin, a zinc-subordinate nonapeptide hormone that controls the separation of juvenile $\mathrm{T}$ cells in the thymus and the capacity to develop fringe $\mathrm{T}$ cells [22]. Then again, $\mathrm{Zn}$ can influence a few parts of monocyte signal transduction and emission of favorable to provocative cytokines, and meddle with the official of leukocyte work related antigen-1 to ICAM-1, accordingly stifling incendiary response [23]. Zinc is associated with different cell forms and has an assortment of immediate and aberrant antiviral properties. It was exhibited that $\mathrm{Zn}$ inadequacy is related to diminished counter acting agent creation, influenced capacity of the intrinsic invulnerable framework (e.g., low normal executioner cell movement), diminished cytokine creation by monocytes, and the chemotaxis and oxidative eruption of neutrophil granulocytes [22]. It likewise results in thymic decay, modified thymic hormones creation, lymphopenia, and damaged cell and counter acting agent interceded reactions that lead to expanded rates and span of disease. Specifically, Zn lack diminishes the quantity of fringe and thymic T cells, their multiplication in light of phytohemagglutinin, and the elements of $\mathrm{T}$ partners and cytotoxic T cells. What's more, Zn inadequacy acts in a roundabout way by decreasing the degrees of dynamic serum thymulin, a zinc-subordinate nonapeptide hormone that controls the separation of juvenile $\mathrm{T}$ cells in the thymus and the capacity of developed fringe T cells [22] [23]. Then again, $\mathrm{Zn}$ can influence a few parts of monocyte signal transduction and emission of favorable to provocative cytokines, and meddle with the official of leukocyte work related antigen-1 to ICAM-1, accordingly stifling incendiary response [22] [23].

Zinc homeostasis may assume a significant job in tweaking the resistant reaction to aggravation, with high groupings of zinc inciting fringe blood monocyte apoptosis 26 and advancing cytokine creation [23]. Then again, low convergences of zinc may smother monocyte capacity and reduction neutrophil phagocytosis [24]. Zinc may likewise collaborate with the aviation route epithelium [25]. Zinc was appeared to significantly affect viral contaminations through regulation of viral molecule section, combination, replication, viral protein interpretation and further delivery for various infections incorporating those associated with respiratory framework pathology [22] [25]. In particular, expanding intracellular $\mathrm{Zn}$ levels through thhhe use of $\mathrm{Zn}$ ionophores, for example, pyrithione and hinokitiol altogether adjust replication of picornavirus, the main source of regular cold [25]. These discoveries for the most part relate to the previous signs of the suppressive impact of zinc on rhinovirus replication starting from the mid-1970s [23]. Also, Zn treatment was appeared to build interferon $\alpha$ $(\mathrm{IFN} \alpha)$ creation by leukocytes [24] and potentiate its antiviral action in rhinovirus-contaminated cells [25].

$\mathrm{Zn}$ lack in rodents brought about a huge increment in proinflammatory TNF $\alpha$ and VCAM-1 articulation and lung tissue renovating, being in part turned around by $\mathrm{Zn}$ supplementation [26]. Zn inadequacy likewise brought about a 
critical adjustment of lung epithelial cell hindrance work through up-guideline of TNF $\alpha$, IFN $\gamma$, and FasR flagging and cell apoptosis in vitro [27]. Zn insufficiency was appeared to up direct intense stage reaction related qualities through incitement of JAK STAT motioning in lungs under septic conditions [27]. Zinc and nitric oxide (NO)-metallothioneine (MT)-Zn pathways were appeared to intervene lung injury because of LPS or hyperoxia [28].

In primary outcome, low levels of $\mathrm{Cu}$ and $\mathrm{Fe}$ were also reported in biological samples of COVID-19 patients as compared to referent subjects. While in the secondary outcome, $\mathrm{Cu}$ and Fe levels were found to be lower than Tuberculosis and viral pneumonia patients.

Iron digestion and anemia may assume a significant job in various organ brokenness conditions in Coronavirus ailment 2019 (COVID-19). Iron is a basic micronutrient for both living humans and microbes [29]. The inborn resistant reaction could confine iron accessibility during diseases to deny its microorganism, a system that would likewise prompt pallor [30].

Iron deficiency, thus, decreases oxygen conveyance to the tissue and may in this way assume a significant job in the advancement of multi organ disappointment. Hence, it is essential to comprehend the connection between pallor, iron digestion and movement of COVID-19, and whether these affiliations vary by age, sex and nearness of interminable conditions. Hemoglobin fixation is one of the most significant determinants of the oxygen-conveying limit of the blood. Low hemoglobin in COVID-19 patients, particularly in populaces in danger of confusions and mortality, could demonstrate that the patients could experience the ill effects of a diminished ability of hemoglobin to help the expanded fringe tissue requests for oxygen due to the hypermetabolic states during contamination [31].

The inborn safe framework arranges authority over iron digestion as a reaction to viral diseases. For viral replication, upgraded cell digestion and ideal iron levels inside host cells are essential [31]. Along these lines, the natural invulnerable framework will respond by diminishing the bioavailability of iron to restrain the replication of the infection during the intense period of contamination. In these conditions, through interleukin- 6 and Toll-like-receptor- 4 ward pathways, the degrees of the liver-determined iron hormone hepcidin-the ace controller of iron homoestasis-could increment and square, the movement of the carrier ferroportin which does iron of the cells, and in this manner decline the measure of iron assimilated from the eating regimen, causing cell sequestration of iron (i.e., primarily in hepatocytes, enterocytes, and macrophages) [31]. Expanded intracellular iron sequestration will prompt an upregulation of cytosolic ferritin which sequesters and stores iron to forestall iron-intervened free extreme harm [31]. The expanded maintenance and capacity of iron inside ferritin in macrophages add to the trademark fall in serum iron focuses and an expansion in serum ferritin fixations as saw in an intense stage reaction [31].

Copper $(\mathrm{Cu})$ has the strong ability to kill irresistible infections, for example, 
bronchitis infection, poliovirus, human immunodeficiency infection type 1 (HIV1), and other encompassed or nonenveloped single- or double-stranded DNA and RNA infections [32]. Cu can upset the lytic pattern of the Coccolithovirus, EhV86 with the expansion underway of ROS [32]. $\mathrm{Cu}^{2+}$ particles can inactivate five wrapped or non enveloped, single or two fold abandoned DNA or RNA infections. The virucidal impact of this $\mathrm{Cu}$ is upgraded by the expansion of peroxide as the blends of $\mathrm{Cu}^{2+}$ particles and peroxide are more proficient than glutaraldehyde in actuating Junin and herpes simplex infections [32]. Copper introduction to human coronavirus $229 \mathrm{E}$ decimated the viral genomes and irreversibly influenced infection morphology, including breaking down of envelope and dispersal of surface spikes [32]. Cupric (II) chloride dihydrate demonstrated the inhibitory impact on the replication of dengue infection, DENV-2 out of a cell culture study [32]. The Cu surfaces can fundamentally lessen the quantity of irresistible flu infection particles. $\mathrm{Cu}$ particles can harm the viral genomic DNA by authoritative and cross-connecting between and inside strands of the genome [33]. Replication of flu an infection was repressed by $\mathrm{Cu}$ by harming the negativesense RNA genome [33]. The contact executing of organisms by $\mathrm{Cu}$ is interceded by the debasement of genomic and plasmid DNA of microorganisms [34].

Individuals with debilitated resistant frameworks are consistently at an expanded danger of irresistible infections, and COVID-19 is no special case. A few reports exhibited that $\mathrm{Cu}$ insufficiency debilitates the human invulnerable reaction. In addition, $\mathrm{Cu}$ inadequacy can over-initiate neutrophils and cause them to develop in the liver, which adds to irritation [35]. A few investigations have indicated that lower absolute cholesterol level might be connected to some degree because of lower $\mathrm{Cu}$ level in grown-ups [35]. Disturbance of lipid pontoons by cholesterol consumption caused an upgrade of infection particles delivered from tainted cells and abatement in the infectivity of infection particles [35].

We also determined the toxic elements (Cadmium and nickel) in biological samples of COVID-19, pulmonary Tuberculosis and pneumonia patients. In primary outcome, higher levels of $\mathrm{Cd}$ and $\mathrm{Ni}$ were reported in biological samples of COVID-19 patients as compared to referent subjects. While in thr secondary outcome, in COVID-19 patients, $\mathrm{Cd}$ and $\mathrm{Ni}$ levels were found to be higher than Tuberculosis and viral pneumonia patients.

Our respiratory system can be affected by the higher concentrations of heavymetals [36]. Versatile complexes can be formed with the metals, inside the cell which may affect the cell functions [36]. In recent decades, various technological innovations have been introduced to the tobacco industry for the improvement of cigarette taste and design, which involves the application of different elements [37]. Tobacco plant tends to absorb toxic metals from soil and pesticides etc [37]. The multi-factorial situations may affect the uptake of toxic elementsTEs, these factors may include the change in the $\mathrm{pH}$ of soil, use of fertilizers, rains and conc. of metals in irrigation water source [38]. The tobacco burning is considered to have released around 87 carcinogenic compounds and TEs, to which 
a smoker is exposed while inhaling the cigarette smoke [38]. The Cd is known to travel through blood, once up-taken by humans, and accumulate in kidneys and liver [39]. The amount of heavy metal exposure may vary from commercial tobacco product to product, since very tobacco company has its own processing method [39]. The toxic elements ingestion can cause pulmonary tuberculosis, atherosclerosis and myocardial infarctions associated disorders by increasing oxidative-stress due to Zn deficiency-an anti-oxidant element [40]. The lack of essential elements supply may enhance the digestion and accumulation of toxic metals that can birth TB, heart related diseases and hypertension [40].

Cadmium is one of the dominant toxic and carcinogenic metals detected in tobacco in higher concentrations [40]. The half life of cadmium in human body is within the range of 13.6 - 23.5 years. Due to its prolonged natural half life, cadmium may bioaccumulate as a result of smoking. The increase the Cd levels in lung tissues have been reported with smoking history and were significantly higher in five lobes of smokers' lungs [41].

The $\mathrm{Ni}$ is known for its nutritional potential to humans in trace levels, but according to IARC $\mathrm{Ni}$ is Group 1 Cancer causing agent [42]. Its concentrations in tobacco are connected immunologically and have been known to cause dermatitis inflammations, asthmatic conditions, pulmonary inflammations and epidermal sensitizations [42]. If sensitization of various trace metals occurs, the cross immunological sensitization is observed as they are known for sharing internal inflammatory activation pathway [42]. The Ni (II) is also known to get attached to Toll-like receptor 4 (TLR4) and transducing pro-inflammatory signal as the TLR4 is a natural lipopolysaccharide known for its inflammatory response [42]. An additional mechanism of Ni transduced inflammation was described by Dolovich et al. in which $\mathrm{Cu}$ binding site in human serum albumin is utilized for producing metal-protein complex [42]. Ni has also a tendency to accumulate in living bodies as metals do [42].

The increase in the Ni levels in lung tissues have been reported with smoking history and were significantly higher in five lobes of smokers' lungs [42]. The Ni content was higher in the fifth lobe of smokers as compared to nonsmokers, but difference was not significant [42]. The high concentration of Ni in different biological samples (blood, body fat, urine) [42] and in amniotic fluid of women [42], indicate systematic absorption from the lungs. In contrast to other toxic metals present in tobacco [42], Nickel is readily transmitted to tobacco smoke. Upon inhalation nickel may find its way into lung tissues and from there it may be scattered to other tissues [42]. The biological half-life of $\mathrm{Ni}$ may last for couple of decades. As $\mathrm{Ni}$ is carcinogenic in nature, its exposure promotes blood, serum, and urine concentrations and it may induce pro-inflammatory immune responses. High exposure to $\mathrm{Ni}$ is related to different physiological disorders, such as, reduce lung function (obstructive lung disease and bronchogenic carcinoma), along with heart disorders, \{myocardial infarction (MI), peripheral arterial disease\}, different types of cancers (cervical cancer, prostate cancer, pan- 
creatic cancer) and various oral pathologies [40].

\section{Conclusions}

This is the first study to analyze the essential trace and toxic elemental level in the biological samples of COVID-19 smoker and nonsmoker male patients. This is our primary outcome, that in the biological samples of COVID-19 patients, the level of essential trace elements ( $\mathrm{Zn}, \mathrm{Cu}$, and $\mathrm{Fe}$ ) were found to be lower than the referents and other secondary out of our study (Tuberculosis and viral pneumonia patients) whilst Higher concentrations of $\mathrm{Cd}$ and $\mathrm{Ni}$ were found in the biological samples of COVID-19 (primary outcome) and secondary outcome (Tuberculosis and viral pneumonia patients). At this time, COVID-19 is a pandemic all over the world. No one person knows the complete history of this disease. This study is carried out for the first time in the world, therefore we cannot compare our results with other studies.

The outcome of this study revealed that the COVID-19 patients have a contradictory behavior of essential trace metal (zinc, iron, and copper) versus toxic element (cadmium and nickel) in the biological samples than the referents of both smoker and nonsmoker subjects. The predominance is more common in patients with smoking habits. Higher levels of cadmium and nickel with simultaneous lower contents of $\mathrm{Cu}, \mathrm{Fe}$, and $\mathrm{Zn}$ may be correlated positively with the end results of coronavirus disease 2019. Serum iron deficiency was one of the features in the patients with COVID-19. The severity and mortality of the disease were closely correlated with serum iron levels. Replacement of Zinc deficiency by cadmium might result in abnormal physiological disorders, as well as other factors, thus may have a role in COVID-19 disease. Since $\mathrm{Cu}$ and zinc are seriously consumed from the jejunum through metallothionein, high portions of zinc (>150 mg/day) can bring about $\mathrm{Cu}$ lack in sound people. It is conceivable that individuals are might be in danger of serious SARS-CoV-2 infection, who are likewise taking $\mathrm{Zn}$ supplements consistently. While high copper levels can be harmful, destinations that are $\mathrm{Cu}$ restricted can bring about pressure reactions by microorganisms that warrant that the $\mathrm{Cu}$ levels must be looked after ideally. Dietary or remedial $\mathrm{Cu}$ supplementations may influence have insusceptible capacity and digestion of different micronutrients and forestall the seriousness of the viral contamination. Accordingly, supplementation of minerals ( $\mathrm{Zn}, \mathrm{Fe}$, and $\mathrm{Cu}$ ) and rectification of mineral deficiencies might be advantageous for COVID19 patients.

\section{Acknowledgements}

We thank the National Centre of Excellence in Analytical Chemistry, University of Sindh to conduct the research work.

\section{Conflicts of Interest}

The authors declare no conflicts of interest regarding the publication of this paper. 


\section{References}

[1] Abid, K., Bari, Y.A., Younas, M., Javaid, S.T. and Imran, A. (2020) Progress of COVID-19 Epidemic in Pakistan. Asia Pacific Journal of Public Health, 32, 154-156. https://doi.org/10.1177/1010539520927259

[2] Waris, A., Atta, U.K., Ali, M., Asmat, A. and Baset, A. (2020) COVID-19 Outbreak: Current Scenario of Pakistan. New Microbes and New Infections, 35, Article ID: 100681. https://doi.org/10.1016/j.nmni.2020.100681

[3] Nawaz, A., Su, X., Barkat, M.Q., Asghar, S., Asad, A., Basit, F., et al. (2020) Epidemic Spread and Its Management Through Governance and Leadership Response Influencing the Arising Challenges Around COVID-19 in Pakistan-A Lesson Learnt for Low Income Countries with Limited Resource. Frontiers in Public Health, 8, Article No. 573431. https://doi.org/10.3389/fpubh.2020.573431

[4] Yeha, C., Houb, M., Tsaic, S., Lin, S.-K., Hsiao, J.-K., Huang, J.-C., et al. (2005) Superoxide Anion Radical, Lipid Peroxides and Antioxidant Status in the Blood of Patients with Breast Cancer. Clinica Chimica Acta, 361, 104-111. https://doi.org/10.1016/j.cccn.2005.05.002

[5] Wessels, I., Maywald, M. and Rink, L. (2017) Zinc as a Gatekeeper of Immune Function. Nutrients, 9, Article No. 1286. https://doi.org/10.3390/nu9121286

[6] Gammoh, N.Z. and Rink, L. (2017) Zinc in Infection and Inflammation. Nutrients, 9, Article No. 624. https://doi.org/10.20944/preprints201705.0176.v1

[7] Percival, S.S. (1998) Copper and Immunity. American Journal of Clinical Nutrition, 67, 1064S-1068S. https://doi.org/10.1093/ajcn/67.5.1064S

[8] Munoz, C., Rios, E., Olivos, J., Brunser, O. and Olivares, M. (2007) Iron, Copper and Immunocompetence. British Journal of Nutrition, 98, S24-S28. https://doi.org/10.1017/S0007114507833046

[9] Gaetke, L.M., Chow-Johnson, H.S. and Chow, C.K. (2014) Copper: Toxicological Relevance and Mechanisms. Archives of Toxicology, 88, 1929-1938.

https://doi.org/10.1007/s00204-014-1355-y

[10] Xu, D., Liu, D., Wang, B., Chen, C., Chen, Z., Li, D., et al. (2015) In Situ OH Generation from $\mathrm{O}_{2}^{-}$and $\mathrm{H}_{2} \mathrm{O}_{2}$ Plays a Critical Role in Plasma-Induced Cell Death. PLoS $O N E, 10$, e0128205. https://doi.org/10.1371/journal.pone.0128205

[11] Litwin, C.M. and Calderwood, S. (1993) Role of Iron in Regulation of Virulence Genes. Clinical Microbiology Reviews, 6, 137-149.

https://doi.org/10.1128/CMR.6.2.137

[12] Doherty, C.P. (2007) Host-Pathogen Interactions: The Role of Iron. Journal of $\mathrm{Nu}$ trition, 137, 1341-1344. https://doi.org/10.1093/jn/137.5.1341

[13] Karadag, F., Cildag, O., Altinisik, M., Kozaci, L.D., Kiter, G. and Altun, C. (2004) Trace Elements as a Component of Oxidative Stress in COPD. Respirology, 9, 33-37. https://doi.org/10.1111/j.1440-1843.2003.00534.x

[14] Li, G.M., Li, Y.G. and Yamate, M. (2007) Lipid Rafts Play an Important Role in the Early Stage of Severe Acute Respiratory Syndrome-Coronavirus Life Cycle. Microbes and Infection, 9, 96-102. https://doi.org/10.1016/j.micinf.2006.10.015

[15] Taborda, N.A., Blanquiceth, Y., Urcuqui-Inchima, S., Latz, E. and Hernandez, J.C. (2019) High-Density Lipoproteins Decrease Proinflammatory Activity and Modulate the Innate Immune Response. Journal of Interferon \& Cytokine Research, 39, 760-770. https://doi.org/10.1089/jir.2019.0029

[16] Murthy, S., Gomersall, C.D. and Fowler, R.A. (2020) Care for Critically Ill Patients with COVID-19. JAMA, 323, 1499-1450. https://doi.org/10.1001/jama.2020.3633 
[17] Fan, J., Wang, H., Ye, G., Cao, X., Xu, X., Tan, W. and Zhang, Y. (2020) Low-Density Lipoprotein Is a Potential Predictor of Poor Prognosis in Patients with Coronavirus Disease 2019. Metabolism, 107, Article ID: 154243. https://doi.org/10.1016/j.metabol.2020.154243

[18] Wei, X., Zeng, W., Su, J., Wan, H., Yu, X., Cao, X., et al. (2020) Hypolipidemia Is Associated with the Severity of COVID-19. Journal of Clinical Lipidology, 14, 297-304. https://doi.org/10.1016/j.jacl.2020.04.008

[19] Huang, W., Li, C., Wang, Z., Wang, H., Zhou, N., Jiang, J., et al. (2020) Decreased Serum Albumin Concentration Indicates Poor Prognosis of COVID-19 Patients: Hepatic Injury Analysis from 2,623 Hospitalized Cases. Science China Life Sciences, 63, 1678-1687. https://doi.org/10.1007/s11427-020-1733-4

[20] Jakovac, H. (2020) COVID-19 and Vitamin D-Is There a Link and an Opportunity for Intervention? American Journal of Physiology-Endocrinology and Metabolism, 318, E589. https://doi.org/10.1152/ajpendo.00138.2020

[21] Grant, W.B., Lahore, H., McDonnell, S.L., Baggerly, C.A., French, C.B., Aliano, J.L., et al. (2020) Evidence That Vitamin D Supplementation Could Reduce Risk of Influenza and COVID-19 Infections and Deaths. Nutrients, 12, Article No. 988. https://doi.org/10.20944/preprints202003.0235.v2

[22] Ibs, K.H. and Rink, L. (2003) Zinc-Altered Immune Function. Journal of Nutrition, 133, 1452S-1426S. https://doi.org/10.1093/jn/133.5.1452S

[23] Novick, S.G. Godfrey, J.C., Pollack, R.L. and Wilder, H.R. (2020) Zinc-Induced Suppression of Inflammation in the Respiratory Tract, Caused by Infection with Human Rhinovirus and Other Irritants. Medical Hypotheses, 149, 347-357. https://doi.org/10.1016/S0306-9877(97)90201-2

[24] Berg, K., Bolt, G., Andersen, H. and Owen, T.C. (2001) Zinc Potentiates the Antiviral Action of Human IFN- $\alpha$ Tenfold. Journal of Interferon \& Cytokine Research, 21, 471-474. https://doi.org/10.1089/10799900152434330

[25] Singh, M. and Das, R.R. (2013) Zinc for the Common Cold. Cochrane Database of Systematic Reviews, No. 6, Article ID: CD001364. https://doi.org/10.1002/14651858.CD001364.pub4

[26] Biaggio, V.S., Chaca, M.V.P., Valdez, S.R., Gomez, N.N. and Gimenez, M.S. (2010) Alteration in the Expression of Inflammatory Parameters as a Result of Oxidative Stress Produced by Moderate Zinc Deficiency in Rat Lung. Experimental Lung Research, 36, 31-44. https://doi.org/10.3109/01902140903061787

[27] Bao, S. and Knoell, D.L. (2014) Zinc Modulates Cytokine-Induced Lung Epithelial Cell Barrier Permeability. American Journal of Physiology-Lung Cellular and Molecular Physiology, 291, L1132-L1141. https://doi.org/10.1152/ajplung.00207.2006

[28] Croix, C.M.S., Leelavaninchkul, K., Watkins, S.C., Kagan, V.E. and Pitt, B.R. (2005) Nitric Oxide and Zinc Homeostasis in Acute Lung Injury. Proceedings of the American Thoracic Society, 2, 236-242.

[29] Cassat, J.E. and Skaar, E.P. (2013) Iron in Infection and Immunity. Cell Host \& Microbe, 13, 509-519. https://doi.org/10.1016/j.chom.2013.04.010

[30] Ganz, T. (2019) Anemia of Inflammation. New England Journal of Medicine, 381, 1148-1157. https://doi.org/10.1056/NEJMra1804281

[31] Drakesmith, H. and Prentice, A. (2008) Viral Infection and Iron Metabolism. Nature Reviews Microbiology, 6, 541-552. https://doi.org/10.1038/nrmicro1930

[32] Sagripanti, J.L., Routson, L.B. and Lytle, C.D. (1993) Virus Inactivation by Copper or Iron Ions alone and in the Presence of Peroxide. Applied and Environmental 
Microbiology, 59, 4374-4376. https://doi.org/10.1128/AEM.59.12.4374-4376.1993

[33] Noyce, J.O., Michels, H. and Keevil, C.W. (2007) Inactivation of Influenza A Virus on Copper versus Stainless Steel Surfaces. Applied and Environmental Microbiolo$g y$, 73, 2748-2750. https://doi.org/10.1128/AEM.01139-06

[34] Grass, G., Rensing, C. and Solioz, M. (2011) Metallic Copper as an Antimicrobial Surface. Applied and Environmental Microbiology, 77, 1541-1547. https://doi.org/10.1128/AEM.02766-10

[35] Raha, S., Mallick, R., Basak, S. and Duttaroy, A.K. (2020) Is Copper Beneficial for COVID-19 Patients? Medical Hypotheses, 142, Article ID: 109814. https://doi.org/10.1016/j.mehy.2020.109814

[36] Jin, Y., Liu, L., Zhang, S., He, R., Wu, Y., Chen, G., et al. (2016) Cadmium Exposure to Murine Macrophages Decreases Their Inflammatory Responses and Increases Their Oxidative Stress. Chemosphere, 144, 168-175.

https://doi.org/10.1016/j.chemosphere.2015.08.084

[37] Wagner, G.J. (1993) Accumulation of Cadmium in Crop Plants and Its Consequences to Human Health. Advances in Agronomy, 51, 173-212.

https://doi.org/10.1016/S0065-2113(08)60593-3

[38] Chiba, M. and Masironi, R. (1992) Toxic and Trace-Elements in Tobacco and Tobacco-Smoke. Bulletin of the World Health Organization, 70, 269-275.

[39] Csalari, J. and Szantai, K. (2002) Transfer Rate of Cadmium, Lead, Zinc and Iron from the Tobacco-Cut of the Most Popular Hungarian Cigarette Brands to the Combustion Products. Acta Alimentaria, 31, 279-288. https://doi.org/10.1556/AAlim.31.2002.3.8

[40] Richter, P.A., Bishop, E.E., Wang, J. and Swahn, M.H. (2009) Tobacco Smoke Exposure and Levels of Urinary Metals in the U.S. Youth and Adult Population: The National Health and Nutrition Examination Survey (NHANES) 1999-2004. International Journal of Environmental Research and Public Health, 6, 1930-1946. https://doi.org/10.3390/ijerph6071930

[41] Tsuchiyama, F., Hisanaga, N., Shibata, E., Aoki, T., Takagi, H., Ando, T., et al. (1997) Pulmonary Metal Distributions in Urban Dwellers. International Archives of Occupational and Environmental Health, 70, 77-84. https://doi.org/10.1007/s004200050190

[42] Dolovich, J., Evans, S.L. and Nieboer, E. (1984) Occupational Asthma from Nickel Sensitivity: I, Human Albumin I the Antigenic Determinant. Occupational and Environmental Medicine, 41, 51-55. https://doi.org/10.1136/oem.41.1.51 